\title{
Prevention of Harmful Algal Blooms by Control of Growth Parameters
}

\author{
Tai-Jin Kim \\ Department of Chemical Engineering, University of Suwon, Hwasung City, South Korea \\ Email: tjkim@suwon.ac.kr
}

How to cite this paper: Kim, T.-J. (2018) Prevention of Harmful Algal Blooms by Control of Growth Parameters. Advances in Bioscience and Biotechnology, 9, 613-648. https://doi.org/10.4236/abb.2018.911043

Received: September 17, 2018

Accepted: November 27, 2018

Published: November 30, 2018

Copyright $\odot 2018$ by author and Scientific Research Publishing Inc. This work is licensed under the Creative Commons Attribution International License (CC BY 4.0).

http://creativecommons.org/licenses/by/4.0/

\section{c) (i) Open Access}

\begin{abstract}
Harmful Algal Blooms (HAB) were investigated to prevent the outbreak of $\mathrm{HAB}$ in both freshwater and seawater. Parameters inducing HAB were volcanic eruption, sunlight, aeolian dust, environmental factors (current, $\mathrm{pH}$, dissolved oxygen, food web, turbulence, growth phase), enzyme, iron, nutrients (carbon, nitrogen, phosphorus, sulfur, silicon, minerals) while the critical growth parameter for the outbreak of HAB was iron (Fe). HAB development was halted in freshwater and seawater due to the sulfur compounds $\left(\mathrm{H}_{2} \mathrm{~S}\right.$, sulfates) inducing the deficiency of the dissolved Fe in the water. The atomic ratio of N/P is commonly known to be $16 / 1$ in freshwater and 176/1 in seawater for HAB. Therefore, nitrogen can be a relatively limiting factor in seawater while phosphorus in freshwater. $\mathrm{HAB}$ could be prevented by control of growth parameters such as $\mathrm{pH}$, temperature, sunlight, turbulence, nitrogen, phosphorus, iron, and sulfur compounds prior to reaching the early exponential phase of algal growth.
\end{abstract}

\section{Keywords}

Prevention, Harmful Algal Blooms, Control, Growth, Parameters

\section{Introduction}

Harmful algae have been the subjects of scientific and societal interest for centuries. There are harmful algal blooms (HAB) in both freshwater and seawater. This is because blooms of toxic dinoflagellates, which are known as "red tides", cause a variety of deleterious effects on aquatic ecosystems. These include negative aesthetic effects such as beach fouling, oxygen deficiency, clogging of fish gills, or poisoning of various organisms [1], as observed recently in Florida [2]. Red tides of Chattonella causing massive fish kills have been recorded in Japan, China, USA (Florida), and South Australia. Chattonella spp. has also been observed 
in Southeast Asia, New Zealand, Brazil, and Europe (North Sea). Red tides of $H$. akashiwo accompanied by fish kills of salmon and yellowtail have occurred in Japan, Canada (British Columbia), New Zealand, Chile, and Scotland. The mechanism by which Chattonella spp. kill fish remains unclear, but suffocation due to gill tissue damage was the ultimate cause of fish death [3]. Kim [4] postulated that $\mathrm{HAB}$ occur only if the environmental factors such as light, nutrients, calm water surface layer, temperature, and $\mathrm{pH}$ could be simultaneously satisfied with the requirements of the mineral ions supplied by the Asian dust as enzymatic cofactors for the rapid bio-synthesis of the macromolecules during $\mathrm{HAB}$ within limited area. The present study examined the prevention of HAB by control of growth parameters including the iron $(\mathrm{Fe})$ in global aeolian dust and water as the key initiator for $\mathrm{HAB}$ while sulfur compounds $(\mathrm{S})\left(\mathrm{H}_{2} \mathrm{~S}\right.$, sulfates) induced $\mathrm{Fe}$ deficiency in the water due to a chemical reaction as sedimentary insoluble $\mathrm{FeS} / \mathrm{FeS}_{2}$ for prevention of $\mathrm{HAB}$.

\section{Experiment}

\subsection{Distribution of Fe and Chlorophyll- $a$ in Freshwater}

Samples of the Asian dust were collected at Anmyon Island $\left(36^{\circ} 34^{\prime} 3^{\prime \prime} \mathrm{N}\right.$, $\left.126^{\circ} 19^{\prime} 45.6^{\prime \prime E}\right)$ nearby Seoul in South Korea by an air pollution monitoring equipment (Tisch Environmental Inc.). Figure 1 showed the weekly distribution of Fe concentration in the Asian dust (red color) and chlorophyll-a in Daechung Lake (blue color) in South Korea from January 2006 to December 2012. Climate condition was clear along the west coast of the Korean Peninsula. Iron was measured by ICP at Korean Basic Science Support Center while chlorophyll-a was determined by method of the standard process test for water contamination. The mean lag times each year between the peak of the Fe concentration and the peak of the chlorophyll-a concentration were shown as follows: 2006 (1.7), 2007 (2.1), 2008 (1.3), 2009 (2), 2010 (2.1), 2011 (0.7), 2012 (1). The average mean lag time was 1.6 weeks or 11 days. Thus, it was observed that the concentration of chlorophyll-a reached the peak value after Fe supply via Asian dust with a lag time of about 11 days.

The cumulative concentration of $\mathrm{Fe}$ in the Asian dust was determined each year by the integration between weekly time intervals defined as below.

$$
\begin{gathered}
(\mathrm{Fe})_{11}=(\mathrm{Fe})_{1} \\
(\mathrm{Fe})_{12}=(\mathrm{Fe})_{1}+(\mathrm{Fe})_{2} \\
(\mathrm{Fe})_{13}=(\mathrm{Fe})_{1}+(\mathrm{Fe})_{2}+(\mathrm{Fe})_{3} \\
\ldots \\
(\mathrm{Fe})_{1 \mathrm{i}}=\sum_{\mathrm{i}=1}^{n}(\mathrm{Fe})_{\mathrm{i}}
\end{gathered}
$$

where i represents the corresponding week. The resultant cumulative concentration of $\mathrm{Fe},(\mathrm{Fe})_{\mathrm{li}}$, was linearly regressed with respect to the weekly time of "i" each year. 

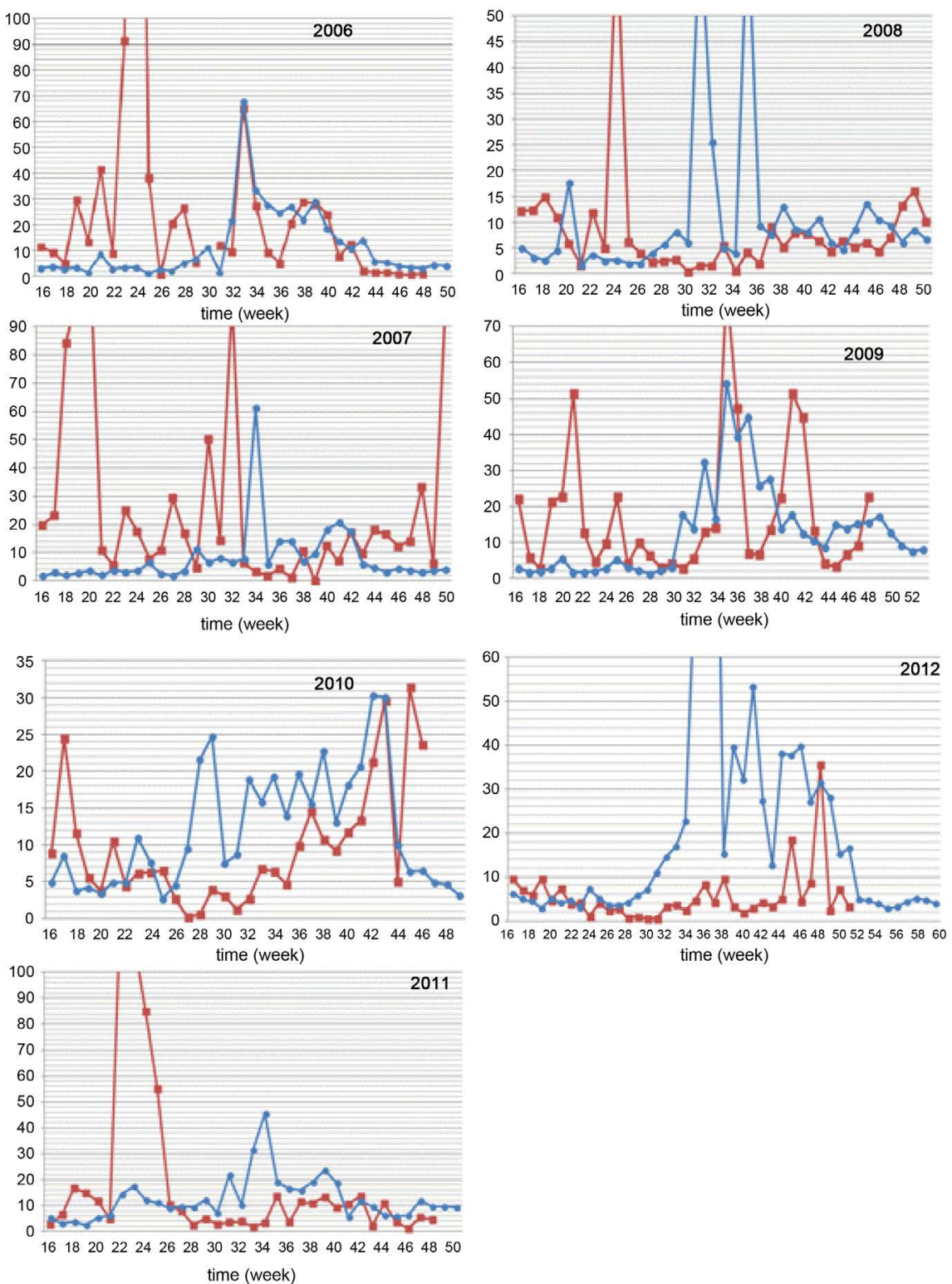

time (week)

Figure 1. The weekly distribution of Fe concentration of the Asian dust $\left(\mu \mathrm{g} / \mathrm{m}^{3}\right)\left(-\mathrm{m}^{-}\right)$on Anmyon Island and chlorophyll-a $(10 \mu \mathrm{g} / \mathrm{l})(--)$ in the Daechung Lake of South Korea from 2006 to 2012 .

Since algae can not grow without Fe, the correlations between the cumulative Fe concentration slope $(\mathrm{x})$ with respect to either the highest concentration of chlorophyll-a (Figure 2(a)) or the highest Cochlonidium concentration (y) (Figure 2(b)) were determined without intercept in Figure 2. The resultant correlations were, $\mathrm{y}=26.095 \mathrm{x}$ with $\mathrm{R}^{2}=0.677$ and $\mathrm{p}$-value $=0.0239$ for chlorophyll- $a$ in the freshwater, and $\mathrm{y}=11,511 \mathrm{x}$ with $\mathrm{R}^{2}=0.389$ and $\mathrm{p}$-value $=0.1375$ for Cochlonidium polykrikoides in the seawater.

Since the highest concentrations of HAB in the freshwater (Figure 2(a)) and in the seawater (Figure 2(a)) were proportional to the cumulative Fe concentration in Figure 2, it could be possible to predict the outbreak of HAB in both 

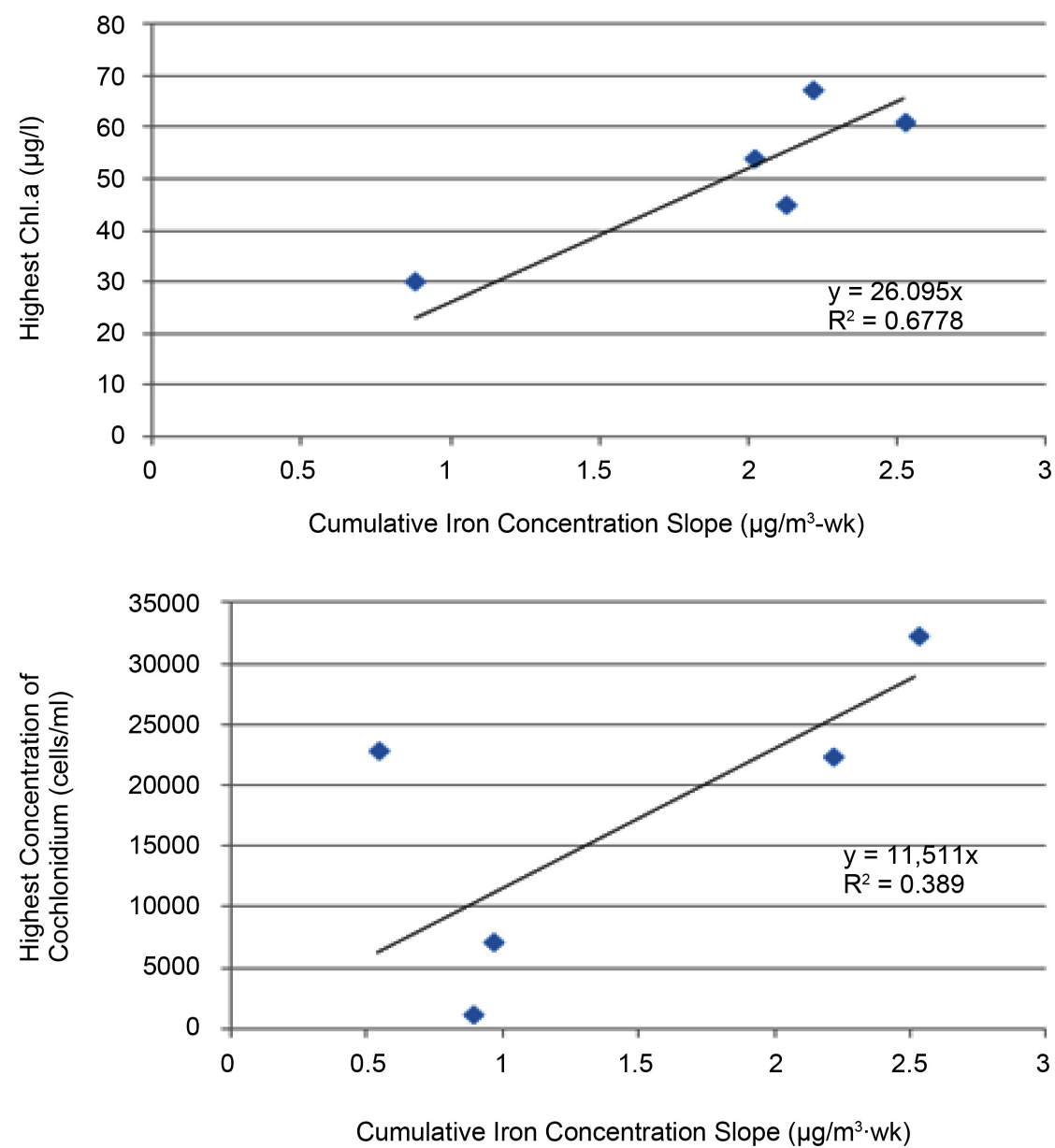

Figure 2. The relationships of the cumulative Fe concentration slope ( $\mu \mathrm{g} / \mathrm{m}^{3}$ wk) with (a) the highest chlorophyll-a concentration $(\mu \mathrm{g} / \mathrm{l})$ and $(\mathrm{b})$ the highest Cochlonidium polykrikoides (cells/ml) from 2006 to 2012 in South Korea.

freshwater and seawater so long as the weekly distribution of Fe concentration in the desert dust was available in advance.

\subsection{Determination of On-Line Cell Concentration of Cochlonidium polykrikoides}

Indonesia is a good reservoir for the growth of Cochlonidium polykrikoides, as shown in Figure 3, due to the following reasons;

1) Many volcanoes (127) to supply nutrients during volcanic eruptions.

2) Strong solar radiation energy at $300 \mathrm{~nm}$ (Figure 4) near Equator.

3) Many islands $(18,000)$ to grow at each seashore.

4) Indonesian Throughflow during monsoon (June, July, August) with fast currents of 8 knots $(4.1 \mathrm{~m} / \mathrm{s})$ for food-webs.

5) Wind driven supply of enriched $\mathrm{Fe}(7 \%-18 \%)$ desert dust from Australia for the growth of $\mathrm{HAB}$.

Therefore, Indonesia is a good starting point for the warm Kuroshio Current which contains Cochlonidium polykrikoide that is driven to fish farmeries in 


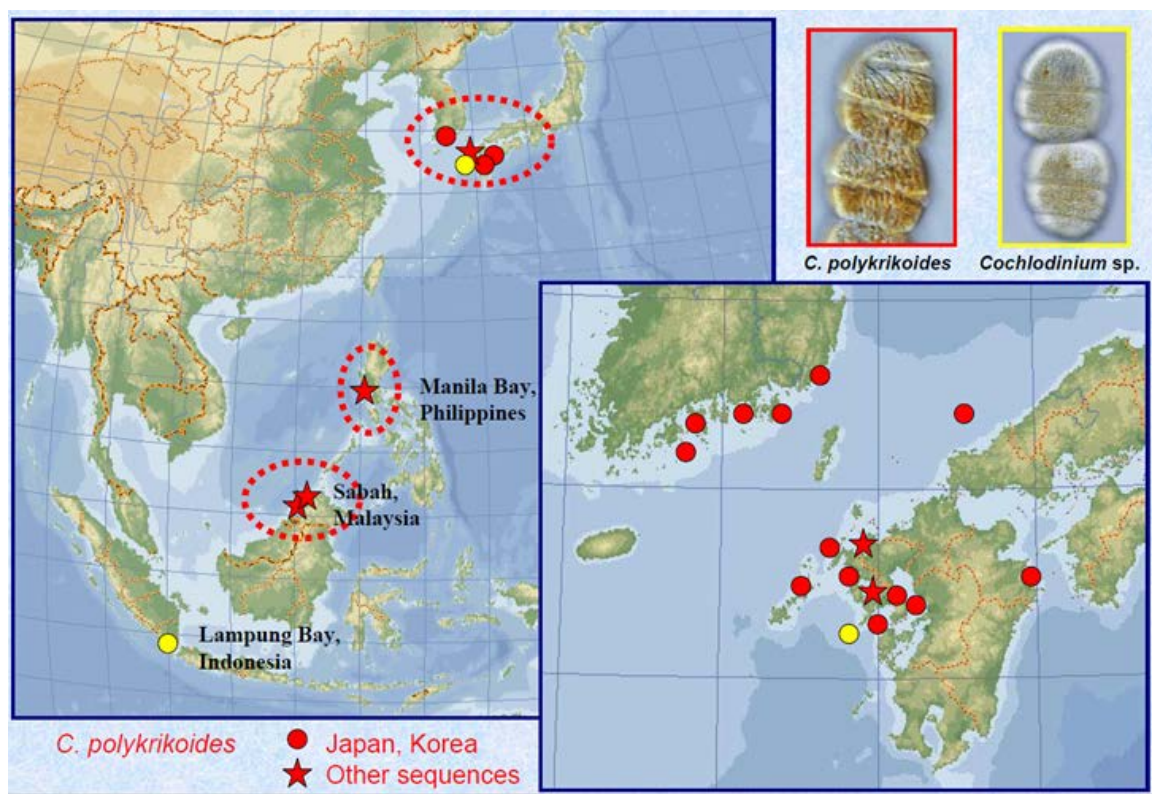

Figure 3. Distribution of $C$. polykrikoides population from Indonesia to Korea and Japan by Iwataki [5].

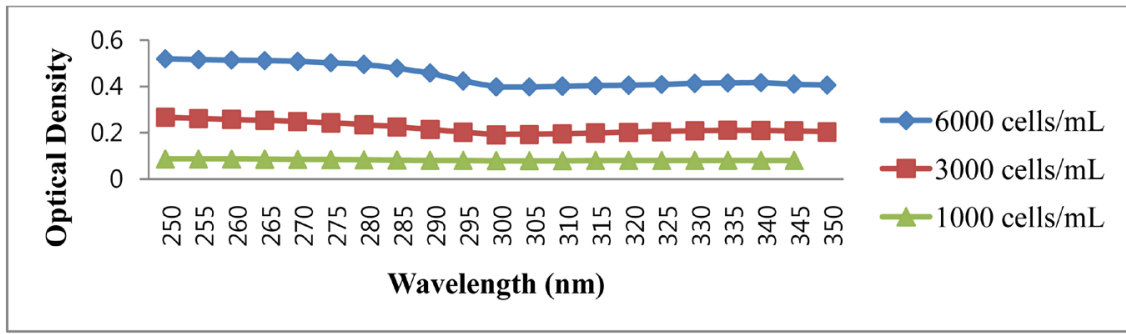

(a)

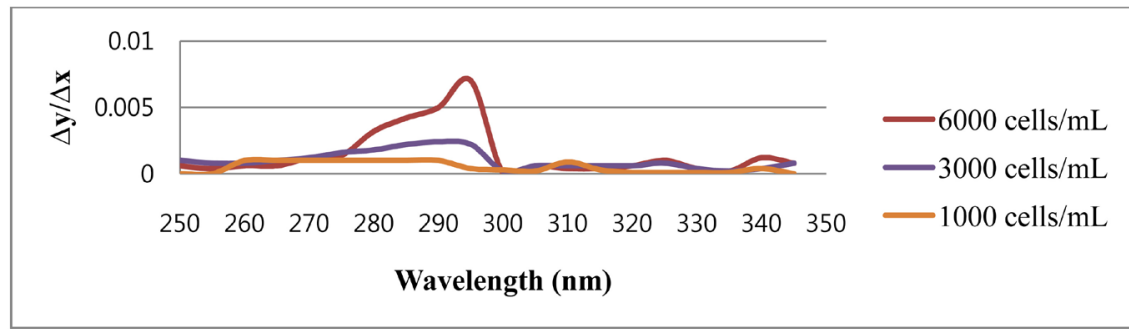

(b)

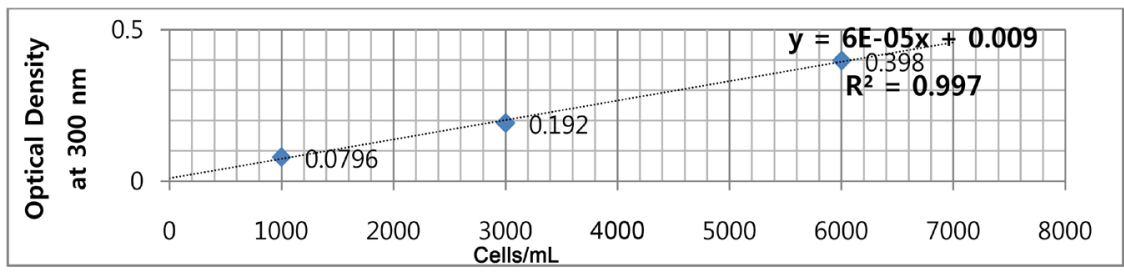

(c)

Figure 4. (a) Scanning data (250 - $350 \mathrm{~nm})$ for Cochlonidium polykrikoides selected from Suh [6]. (b) The optimal optical density for the measurement of Cochlonium polykrikoides was determined at $300 \mathrm{~nm}$ based on the first derivatives of individual scannings at 1000, 3000, 6000 cells $/ \mathrm{ml}$. (c) Distribution of the cell concentrations of Cochlonidium polykrikoides at $1000,3000,6000$ cells $/ \mathrm{ml}$ showed the high linearity $\left(\mathrm{R}^{2}=0.9972\right)$ with the optimal optical density at $300 \mathrm{~nm}$. 
Korea and Japan during summer, as shown in Figure 3.

The scanning data $(250-350 \mathrm{~nm})$ of optical density for Cochlonidium polykrikoides [6] at cell concentration of 1000, 3000, and 6000 cells/ml (Figure 4(a)) were plotted to obtain the first derivatives for searching the optimal optical density, which suggested $300 \mathrm{~nm}$ as the optimal optical density for the measurement of Cochlonidium polykrikoides, as shown in Figure 4(b). Figure 4(c) showed that the cell concentrations of Cochlonium polykrikoides were linearly $\left(\mathrm{R}^{2}=\right.$ 0.9972) proportional to the optical densities at $300 \mathrm{~nm}$, which could be caused by its preference for ultraviolet band with high energy in accordance with Einstein-Planck relation. It was thus possible to determine the cell concentration of Cochlonidium polykrikoides via an on-line method at $300 \mathrm{~nm}$ instead of the present tedious method of cell number counting by microscope after off-line sampling. It was postulated that on-line real-time monitoring of Cochlonidium polykrikoides could be possible for the early warning of HAB in conjunction with a smart phone system so long as a portable detector was available at 300 nm.

\subsection{Prevention of Harmful Algal Blooms by Sulfur Compounds}

Figure 5 showed that iron deficiency $(-\mathrm{Fe})$ inhibited the algal growth while iron enrichment $(+\mathrm{Fe})$ enhanced the phytoplankton productivity. However, fresh $100 \%$ Japanese Ontake volcanic ash with enriched sulfur compounds (V100) showed reduced algal-growth.

Hydrogen sulfide $\left(\mathrm{H}_{2} \mathrm{~S}\right)$ is produced by 4 routes; volcanic gas $(0.04 \%-0.68 \%)$, sulfur oxidizing bacteria such as Beggiatoa, sulfate reducing bacteria (SRB) such as Desulfovibrio desulfuricans, and decomposed microorganism [8].

Standard $\mathrm{H}_{2} \mathrm{~S}$ gas with $50 \mathrm{ppm}$ (RIGAS in Korea) with a flow rate of $2 \mathrm{~L} / \mathrm{min}$

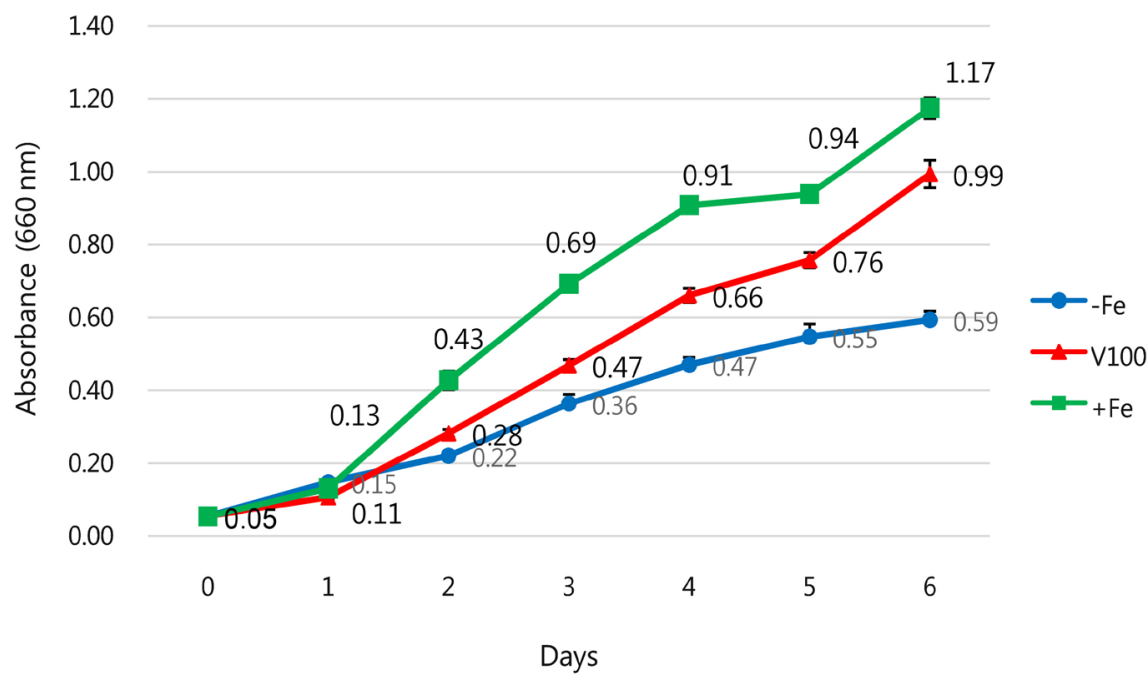

Figure 5. Growth curve of Chlorella vulgaris with various JM media; with its own $\mathrm{Fe}(+\mathrm{Fe}$, ---), fresh $100 \%$ volcanic ash (V100, - $\Delta-$ ), without its own $\mathrm{Fe}$ (Fe,---). Standard deviation was expressed by each error bar for three measurements with excellent reproducibility, modified from Kim [7]. 
for 10 minutes was bubbled into 1 liter of the algal freshwater dissolved $25 \mathrm{~g}$ $\mathrm{FeSO}_{4} \cdot 7 \mathrm{H}_{2} \mathrm{O}$. Algae were sedimented due to lack of $\mathrm{Fe}$ in freshwater induced by $\mathrm{H}_{2} \mathrm{~S}$ bubbling. The sedimentary materials were filtered to analyze by X-ray diffractometer (XRD) (Model Dmax2500/PC) for the presence of iron sulfides in the form of Greigite- $\mathrm{Fe}_{3} \mathrm{~S}_{4}$ among sulfur and iron oxide, as shown in Figure 6. Quantitative analysis of Figure 6 implied that the crystallinity of $\mathrm{Fe}_{3} \mathrm{~S}_{4}$ constituted $4.06 \mathrm{wt} \%$ of total sedimentary materials among amorphous peaks. It was thus evident that sulfur compounds bind Fe to sediment in black iron sulfide and deprive Fe from the growth of phytoplankton. Decomposed microorganism produced $\mathrm{H}_{2} \mathrm{~S}$ as high as $0.122 \%$ [9] or $1220 \mathrm{ppm}$ while the safe level is below 10 ppm [10]. Therefore, the disposable Biogas with $\mathrm{H}_{2} \mathrm{~S}$ of $0.2 \%$ - 3.5\% [10] could be bubbled into both of freshwater and seawater cautiously to prevent HAB typically in Florida [2] during the early algal growth phase.

\section{Results and Discussion}

\subsection{Volcanic Eruption}

Volcanic gases are commonly composed in the order of $\mathrm{H}_{2} \mathrm{O}(37 \%-97.1 \%)$,

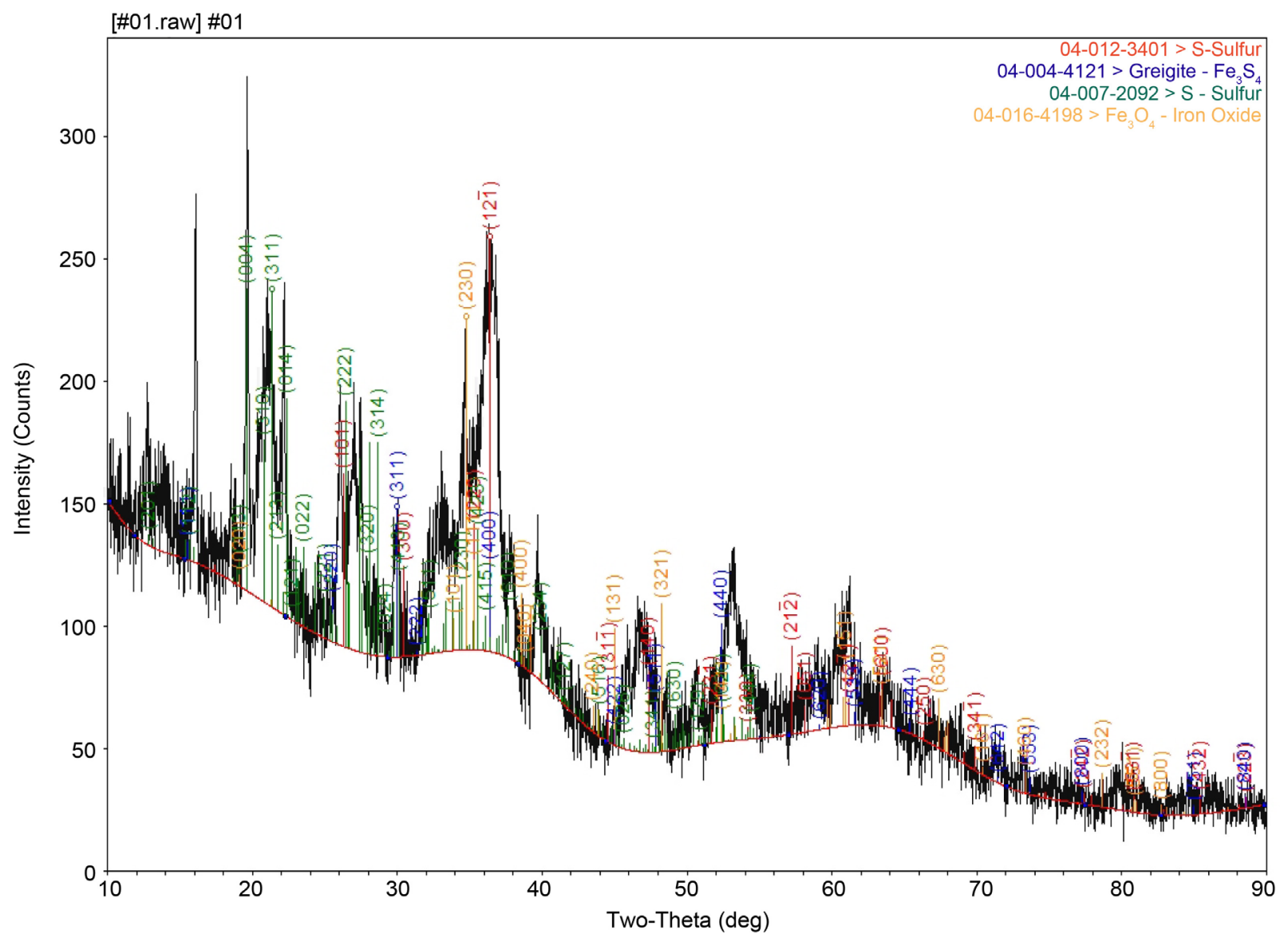

KIST

[JADEIADmin]<D:IXRD result|2018-01101S0102-KTJ> Monday, January 15, 2018 01:55p (MDI/JADES)

Figure 6. Distribution of X-ray diffractometer (XRD) pattern for the sedimentary materials induced by the chemical reaction between dissolved $\mathrm{FeSO}_{4} \cdot 7 \mathrm{H}_{2} \mathrm{O}$ and $\mathrm{H}_{2} \mathrm{~S}$ gas bubbling in distilled water. 
$\mathrm{CO}_{2}, \mathrm{SO}_{2}(0.50 \%-11.8 \%), \mathrm{H}_{2}, \mathrm{CO}, \mathrm{H}_{2} \mathrm{~S}(0.04 \%-0.68 \%), \mathrm{HCl}$, and $\mathrm{HF}$ during volcanic eruptions [11]. Volcanic ash has an iron complex in the forms of $\mathrm{Fe}_{2} \mathrm{O}_{3}$, $\mathrm{Fe}_{3} \mathrm{O}_{4}, \mathrm{FeCl}_{2}, \mathrm{FeCl}_{3}, \mathrm{FeF}_{2}, \mathrm{FeF}_{3}, \mathrm{FeS}, \mathrm{FeS}_{2}, \mathrm{FeSO}_{4}$ and $\mathrm{Fe}_{2}\left(\mathrm{SO}_{4}\right)_{3}$ [12]. The primary producers in the ocean that absorb iron $(\mathrm{Fe})$ are phytoplankton or cyanobacteria, while hematite $\left(\mathrm{Fe}_{2} \mathrm{O}_{3}\right)$ and geothite $(\mathrm{FeOOH})$ in the aeolian dust are associated with fine $(0.3-1 \mu \mathrm{m})$ particles with long residence times (days) in the atmosphere and thus potentially long transport paths [13]. Fe is essentially required during photosynthesis, electron transport, energy transfer, $\mathrm{N}$ (nitrate and nitrite) assimilation, and cyanobacteria $\mathrm{N}_{2}$-fixation by nitrogenase complex with 32 to $36 \mathrm{Fe}$ atoms [14]. Under aerobic conditions typifying surface waters, Fe exists in ferric $\left(\mathrm{Fe}_{(\mathrm{aq})}^{3+}\right)$ form.

Increases of reductant under anoxic conditions [15], NADPH-oxidoreductase/ ferric reductase [13], iron-reducing bacteria [16], photochemical, superoxide, humic acid and fulvic acid in peat [17], reduce $\mathrm{Fe}_{(\mathrm{aq})}^{3+}$ to $\mathrm{Fe}_{(\mathrm{aq})}^{2+}$, to be transferred into the algal cytosol by $\mathrm{Fe}_{(\mathrm{aq})}^{2+}$ permease [13] for the biosynthesis of macromolecules while excess Fe is stored in ferritin or cellular Fe pool [18]. The only missing ingredient after phytoplankton blooms is the dissolved $\mathrm{Fe}_{(\mathrm{aq})}^{2+}$ in HNLC (High Nutrient, Low Chlorophyll) regions unless there are further Fe inputs from aeolian dust or volcanic ash.

As seen in Figure $7, \mathrm{H}_{2} \mathrm{~S}$ is produced by 4 routes; 1) directly from volcanic gas $(0.04 \%-0.68 \%)$ with relatively high solubility $\left(0.3 \mathrm{~g} / 100 \mathrm{~g} \mathrm{H}_{2} \mathrm{O}\right)$ compared to extremely low solubility of FeS $\left.\left(4.4 \times 10^{-5}\right), 2\right)$ from sulfur oxidizing bacteria such as Beggiatoa, 3) from soluble sulfate by sulfate reducing bacteria such as Desulfovibrio desulfuricans, 4) and decomposed microorganism [8].

The more $\mathrm{H}_{2} \mathrm{~S}$ available from either the volcanic gas and sulfur oxidation, or soluble sulfates through sulfate reducing bacteria, the more sedimentation occurs in the forms of $\mathrm{FeS}$ and $\mathrm{FeS}_{2}$. Therefore, it can be seen that the volcanic eruption enhances the formation of $\mathrm{FeS}$ and $\mathrm{FeS}_{2}$, which induces less and less $\mathrm{Fe}$ available to algae to be the Fe limited condition of LC (Low-Chlorophyll). On the other hand, nutrients such as nitrate, phosphate and silicate are fairly soluble and utilized by algae. However, since Fe was limited, the growth of algae was reduced [19] and thus nutrients were less utilized and further enriched to be HN (High-Nutrient).

\subsection{Sunlight with Algae Size}

Photosynthesis is the process by which sunlight energy is transformed into chemical energy to produce organic compounds that serve as cellular building blocks and energy reserves. In the first phase of the light dependent reactions, light energy reaching reaction center chlorophyll-a molecules, with the formula of $\mathrm{C}_{55} \mathrm{H}_{68} \mathrm{O}_{5} \mathrm{~N}_{4} \mathrm{Mg}$, is stored in ATP and NADPH. The reverse reaction of photosynthesis is the cellular respiration, which occurs during the night for cells to obtain energy in ATP for maintenance of the cell and its growth. The respiration process produces 38 ATP, passing through the serial metabolic pathways of 


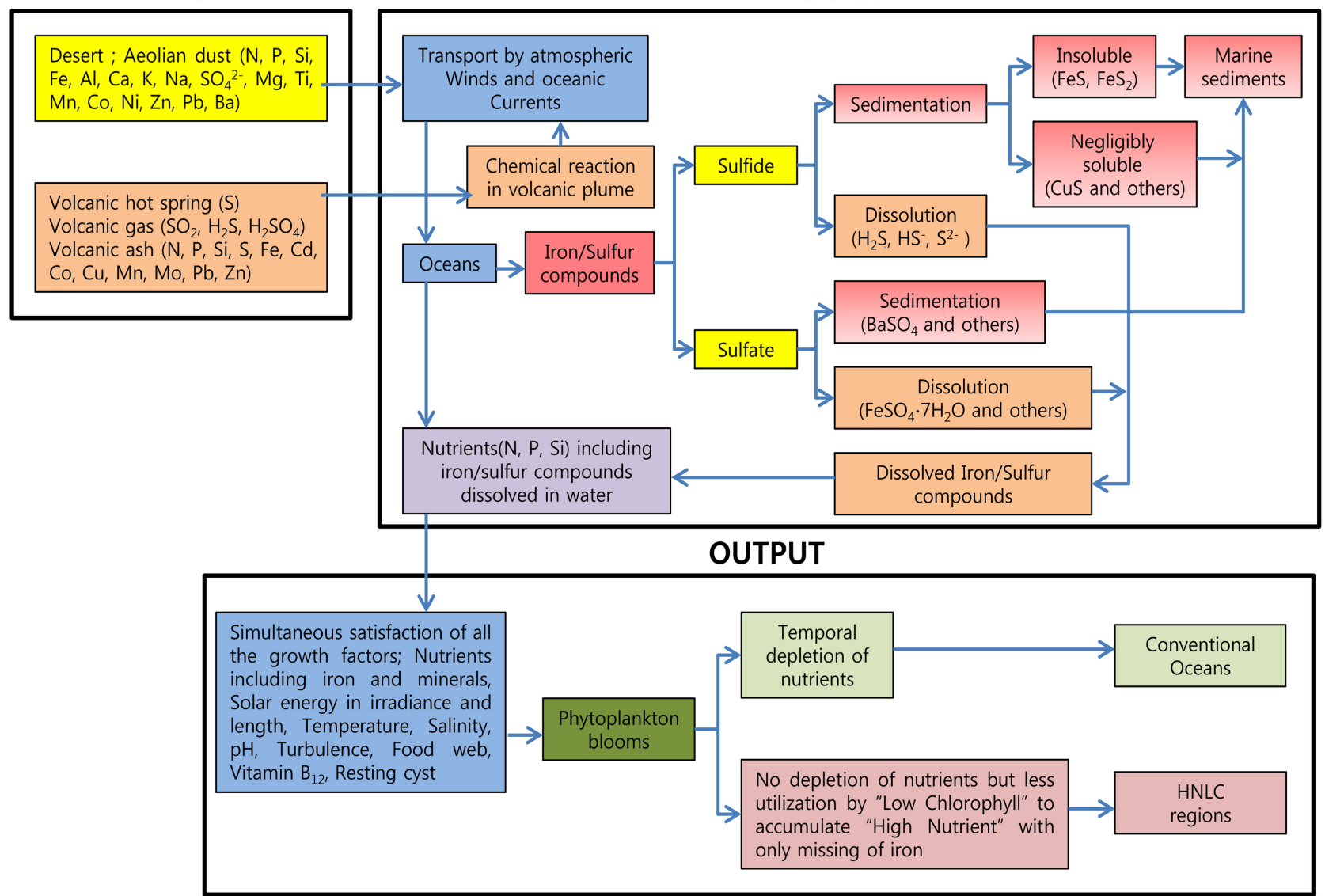

Figure 7. Schematic block diagram of iron $(\mathrm{Fe})$ and sulfur compounds (S) from the input of desert and volcano to the output of oceanic regions via the transport process of atmospheric winds and oceanic current.

glycolysis and citric acid cycle, which require ten and eight individual enzymes along with specific metal ions, respectively.

Photosynthetically Active Radiation (PAR) consists of the light measured from a range of $400 \mathrm{~nm}$ to $700 \mathrm{~nm}$ [20]. Since the flux is defined as the quantity per unit time per unit area, total light energy is given by,

Total light energy $=($ Energy Flux $) \times($ Area $) \times($ Period of Radiation $)$

Table 1 shows the seasonal HAB with various algae sizes. Anabaena can bloom during early winter due to its small surface area, requiring small amount of light energy flux (low light intensity and short radiation period). Microcystis has a relatively large surface area, requiring a large amount of light energy flux (strong light intensity and long radiation period). As for cyanobacteria, the order of large surface area in Table 1 is Microcystis $>$ Aphanizomenon $>$ Oscillatoria > Anabaena. Since more energy is required for a large surface area, diatoms of Cyclotella and Stephanodicus have relatively small surface areas for blooming in spring. As for Cochlonidium polykrikoides, they form several cells connected together to get more solar energy during summer and early fall with a preference for the highest energy band at $300 \mathrm{~nm}$, as verified in Figure 4(b). Cochlonidium 
Table 1. Characteristics of typical species with various algae size causing seasonal HAB.

\begin{tabular}{|c|c|c|c|c|c|}
\hline Species & Type & $\begin{array}{c}\text { Diameter } \\
(\mu \mathrm{m}) / \text { Length }(\mu \mathrm{m})\end{array}$ & Surface Area $\left(\mu \mathrm{m}^{2}\right)$ & Blooming Season & Cell (Number) \\
\hline Cyanobacteria, Anabaena & Cylinder & $7 / 80$ & 1758 & $\begin{array}{c}\text { Fall, } \\
\text { Early Winter }\end{array}$ & Single \\
\hline Cyanobacteria, Microcystis & Sphere & $2.6-5.4 / 260-540$ & $\begin{array}{c}49,063 \\
(13,800,000-123,609,000)\end{array}$ & Spring, Summer & Colony (100) \\
\hline Cyanobacteria, Oscillatoria & Cylinder & $10 / 350$ & 10,990 & Fall & Single \\
\hline $\begin{array}{l}\text { Cyanobacteria, } \\
\text { Aphanizomenon }\end{array}$ & Cylinder & $2.8 / 100$ & $\begin{array}{c}70,650 \\
(1,413,000)\end{array}$ & Spring, Summer & Colony (20) \\
\hline $\begin{array}{c}\text { Cyanobacteria, } \\
\text { Cyclotella }\end{array}$ & Disk & $27 / 30$ & 2543 & Spring & Single \\
\hline $\begin{array}{c}\text { Diatom, } \\
\text { Stephanodiscus }\end{array}$ & Disk & $100 / 20$ & 15,700 & Spring & Single \\
\hline $\begin{array}{c}\text { Dinoflagellate, Cochlonidium } \\
\text { polykrikoides }\end{array}$ & Cylinder & $\begin{array}{c}35 / 25 \\
(35 / 200)\end{array}$ & $\begin{array}{c}17,172 \\
(192,000)\end{array}$ & Summer, Early Fall & Colony (8) \\
\hline
\end{tabular}

polykrikoides has a diameter of $35 \mu \mathrm{m}$ with several cells connected together. Therefore, any cloth around the fish farmery with pore diameter less than $35 \mu \mathrm{m}$ may block the penetration of Cochlonidium polykrikoides into the fish farmery. Since traffic signal yellow $(590 \mathrm{~nm}$ ) shows the least absorption (\%) for chlorophyll-a, artificial LEDs with $590 \mathrm{~nm}$ could be installed in the fish farmery to repel Cochlonidium polykrikoides, requiring the highest solar energy at $300 \mathrm{~nm}$ (Figure 4(b)).

\subsection{Desert Dust}

Major aeolian dust events arise from the Sahara and Sahel deserts ("African dust"), the Australian deserts ("Australian dust"), and the Taklamakan and Gobi deserts and the Loess plateau ("Asian dust") [21]. Tanaka and Chiba [22] compared the annual mean global dust fluxes by regions: Africa (61\%; North 58 , South 3), Asia (30.5\%; Arabia 12, Central 7.5, East 11), Australia (6\%), and America (2.1\%; North 0.1, South 2). Asian dust from northern China and Mongolia [23] occur all year round in the dust source regions and some of them have an adverse impact on environment, eco-systems and human health socio-economic activities not only in the source regions but in the far downwind regions. Iron (Fe) and phosphorus in African dust [24] colimited the nitrogen fixation of phytoplankton in the eastern tropical North Atlantic. Sahara dust storms carry heavy metals, bacteria, and other pathogens to the Caribbean, causing coral death. In Figure 8, two images from NASA's Total Ozone Mapping Spectrometer (TOMS) instrument showed dust blowing off the Sahara in Africa and crossing the tropical Atlantic. 

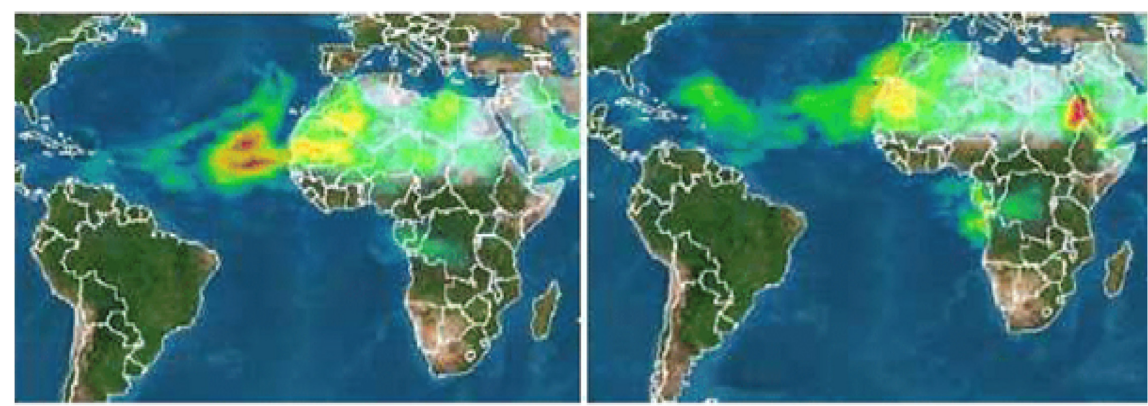

(a)

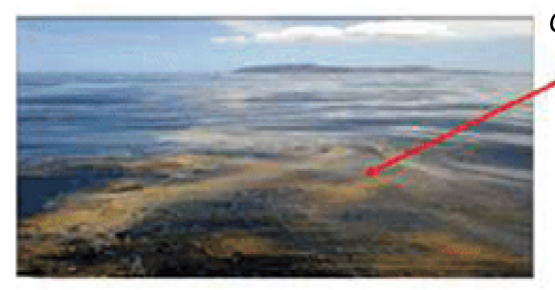

\section{Canary Islands}

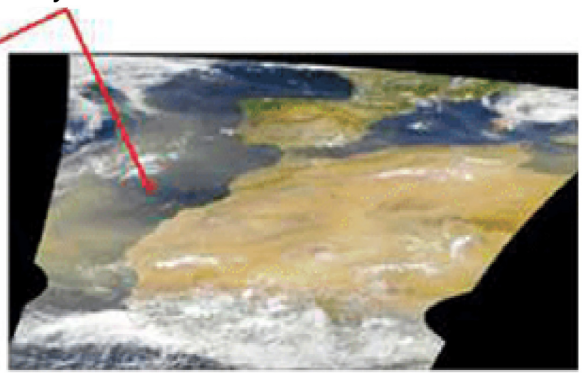

(b)

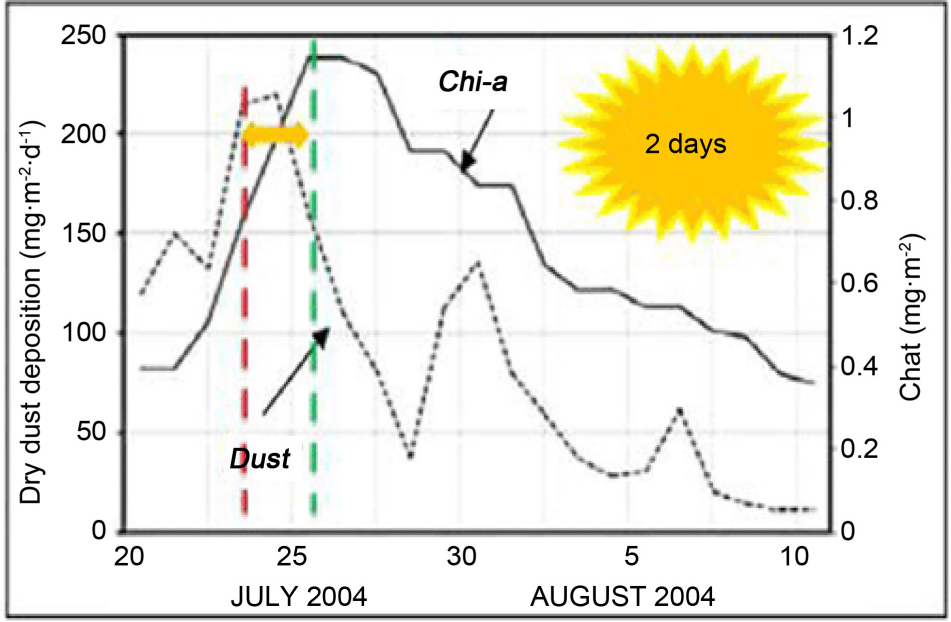

(c)

Figure 8. (a) Satellite images of the African dust event on June 17, 1999 (Left) as dust leaves Africa, and on July 2, 1999 (Right) as the dust approaches North America. (b) Bloom of Trichodesmium-Canary Islands, August 2004 (Left) and just over w Africa, July 2004 (Right). (c) Chlorophyll- $\alpha$ vs. African dry dust deposition (model); no upwelling during the event [25].

Many large oceanic areas do not have enough dissolved Fe necessary to support large populations of phytoplankton. Dust carries Fe from the land to the open ocean, supplying needed $\mathrm{Fe}$, leading to phytoplankton blooms covering large areas of the North Atlantic and Caribbean. Nitrogen, Fe and phosphorus in Saharan dust fertilized plankton blooms in the tropical eastern Atlantic of the Canary Islands and affected exchange of carbon dioxide between atmosphere and oceans, as shown in Figure 8(a) \& Figure 8(b). Two days of lag time of algal 
blooms appeared on the basis of peak-to-peak value as shown in Figure 8(c), whereas dry dust deposition was obtained by modeling [25]. During the last decade there has been a significant rise in observations of blooms of the toxic cyanobacterium Lyngbya majuscula along the east coast of Queensland, Australia. L. majuscula productivity was significantly $(\mathrm{p}<0.05)$ stimulated by soil extracts, which were high in phosphorus, $\mathrm{Fe}$ and organic carbon [15]. It is well-known that Asian desert dust particles can be transported long distances and reach the North American Continent, and oceanic deposition encourages phytoplankton growth in the North Pacific Ocean by natural Fe fertilization [26]. The contributions of $\mathrm{Fe}$, nitrogen, and phosphate by the dust deposition from Asian dust storms promoted the growth of cyanobacterium Synechococcus in the Kuroshio Current [27], which is the common prey of red-tide dinoflagellates and heterotropic nanoflagellates [28]. Asian dust particles were confirmed to be carriers of bacteria such as Antinobacteria, Bacilli, Sphingobacteria [21]. However, residents living nearby the origins of Asian dust such as Aksu, Dunhuang, Zhenbeitai, and Changwu [29], did not have some serious diseases such as cancer or miscarriages although many people have complained of the severe difficulty of breathing and shortage of sunlight due to the Asian dust. On the other hand, people living in the downwind regions passing through industrial complexes such as Bejing and Dailian have suffered severely because of Asian dust particles along with nitrate, ammonia, sulfate, and hydrocarbons from coal combustions [30], which have recently made serious social issues in China.

Many researchers have empirically analyzed the composition of the Asian dust with eight major elements in the parenthesized weight percentage order of $\mathrm{Si}$ (27) $>\mathrm{Ca}(10)>\mathrm{Al}(7)>\mathrm{Fe}(5)>\mathrm{K}(3)>\mathrm{Mg}(2) \gg \mathrm{Ti}(0.5) \gg \mathrm{Mn}(0.1)$ [29]. Table 2 shows the necessary elements for algal growth compared correspondingly with components of wind carried particles of Asian dust. HAB could be thus prevented by blocking the deposition of desert dust.

\subsection{Iron}

Iron $(\mathrm{Fe})$ is the second most abundant metal and the fourth most abundant element by weight in the earth's crust while Asian dust contain iron commonly expressed in iron oxides [31] ranging from 4 to 6 weight percent depending upon different sources [13]. Fe is typically released into the soil or into the ocean through the weathering of rocks or through volcanic eruptions. Fe is an important limiting nutrient for $\mathrm{HAB}$, which is used to produce chlorophyll and protein, as shown in Figure 9.

Photosynthesis depends on adequate Fe supply, whose concentration in water is quite low because of low solubility $\left(<1 \mathrm{mg} \cdot \mathrm{L}^{-1}\right.$ in freshwater). The primary producers in the ocean that absorb $\mathrm{Fe}$ are typically phytoplankton or cyanobacteria. Fe is then assimilated by consumers when they eat the bacteria or plankton, the latter providing a crucial source of food to many large aquatic organisms such as fish and whales. When animals, fishes and plankton die, decomposing 
Table 2. Algal growth necessary elements compared with components of particles of Asian dust.

\begin{tabular}{ccc}
\hline & Algal Growth Element [14] & Asian Dust \\
\hline Element & Major Function & Zhang [29] \\
$\mathrm{N}$ & Amino Acid & $\mathrm{o}$ \\
$\mathrm{P}$ & ATP/DNA & 0 \\
$\mathrm{Cl}$ & Photosynthesis & $\mathrm{o}$ \\
$\mathrm{S}$ & Photosynthesis & $\mathrm{o}$ \\
$\mathrm{Si}$ & Cell Wall & $\mathrm{o}$ \\
$\mathrm{Na}$ & Nitrate Reductase & $\mathrm{o}$ \\
$\mathrm{Ca}$ & Alginates & $\mathrm{o}$ \\
$\mathrm{Mg}$ & Chlorophyll & $\mathrm{o}$ \\
$\mathrm{Fe}$ & Nitrate Reductase & $\mathrm{o}$ \\
$\mathrm{K}$ & Enzyme Cofactor & $\mathrm{o}$ \\
$\mathrm{Mo}$ & Nitrate Reductase & - \\
$\mathrm{Mn}$ & Photosystem II & $\mathrm{o}$ \\
$\mathrm{Zn}$ & Carbonic Anhydrase & $\mathrm{o}$ \\
$\mathrm{Cu}$ & Photosystem II & $\mathrm{o}$ \\
$\mathrm{Co}$ & Vitamin $\mathrm{B}_{12}$ & - \\
$\mathrm{V}$ & Nitrogenases & $\mathrm{o}$ \\
\hline
\end{tabular}

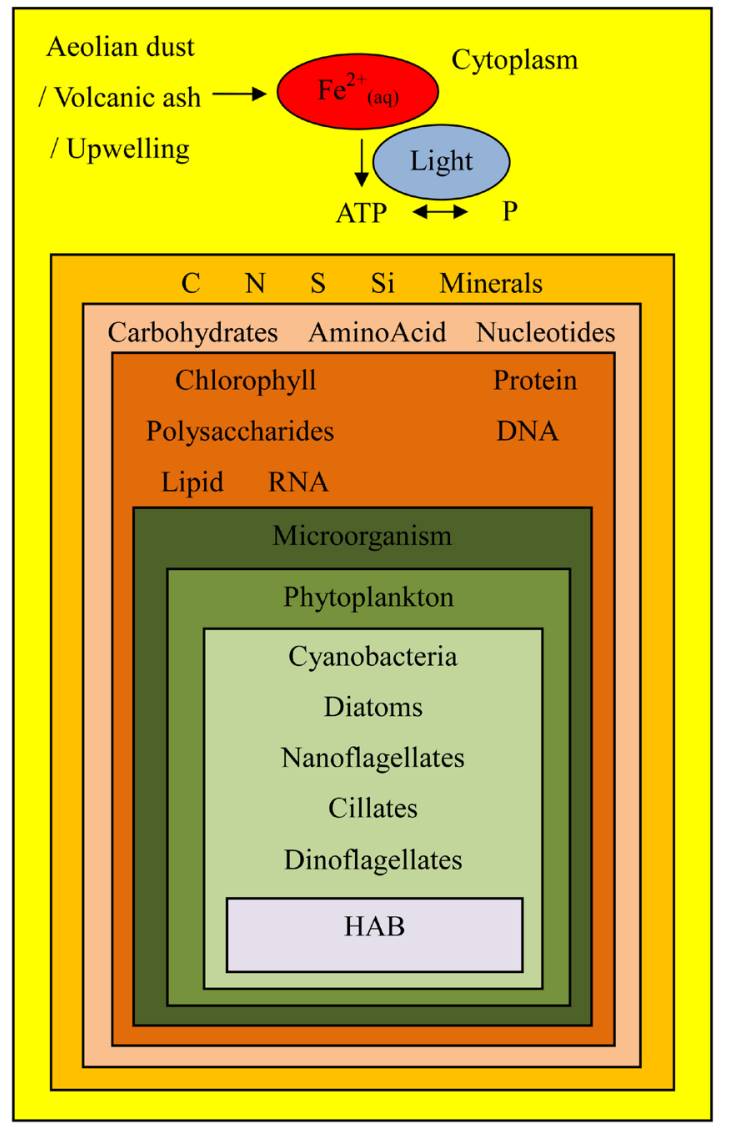

Figure 9. Iron, sunlight, phosphorus, and nutrients for $\mathrm{HAB}$ in both of the freshwater and the seawater. 
bacteria return Fe to the soil and the water [32]. Haematite $\left(\mathrm{Fe}_{2} \mathrm{O}_{3}\right)$ and goethite $(\mathrm{FeOOH})$ tend to be associated with fine $(0.3-1 \mu \mathrm{m})$ desert particles, with long residence times (i.e. days) in the atmosphere and thus potentially long transport paths. Haematite content varies between $0.6 \%$ and $3.4 \%$ (by volume). In wt.\% goethite is 2 - 3 times higher than that of haematite. Similar dominance of goethite has been reported for samples from the Sahara and the Sahel [13]. Under oxic conditions typifying surface waters, Fe exists largely in the oxidized ferric $\left(\mathrm{Fe}^{3+}\right)$ form; as insoluble oxides, hydroxides, and carbonates which readily precipitate and deposit in the sediments. Under anoxic conditions, Fe may be released from the sediments [33] as a more reduced $\mathrm{Fe}^{2+}$ prior to $\mathrm{HAB}$, as stepwise shown in Figure 10. It seems that the utilization rate of iron is mainly governed by the dissociation process of iron oxide to aqueous phase $\mathrm{Fe}^{3+}$, its delivery time from the land to the river and coast, following periods of heavy rainfall, and the release of $\mathrm{Fe}^{2+}$ from Fe complex. When dissolved oxygen (DO) is so low, the binding of iron oxides with phosphorus sediments is broken-down to release the phosphorus and the oxygen, the latter being utilized by the iron-reducing bacteria. For example, iron-reducing bacteria of Shewanella algae BrY reduces ferric iron $\left(\mathrm{Fe}^{3+}\right)$ to ferros iron $\left(\mathrm{Fe}^{2+}\right)$ by the following reactions [34], where maximum concentration of $\mathrm{Fe}^{2+}$ in aqueous phase was reached in 15 hours [16].

Figure 10 informs us that $\mathrm{Fe}_{(\mathrm{aq})}^{3+}$ is changed to $\mathrm{Fe}_{(\mathrm{aq})}^{2+}$ for $\mathrm{HAB}$ under conditions such as 1) Increase of reductant under anoxic condition, 2) NADPH-

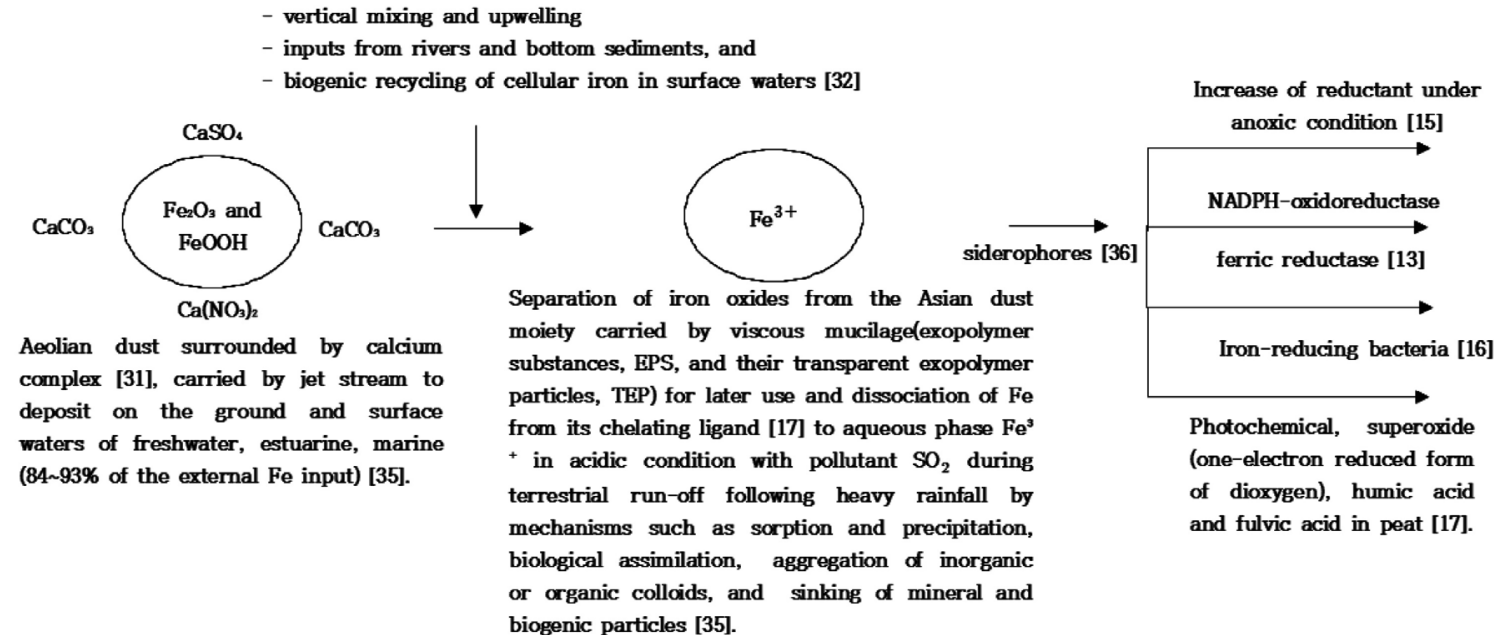

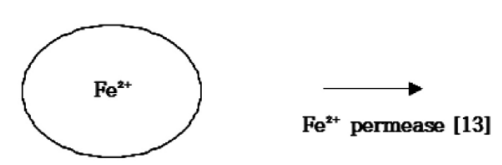

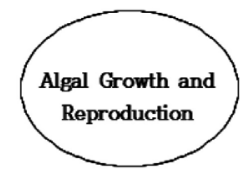

Transfer $\mathrm{Fe}^{2+}$ into the cytosol for the biosynthesis of macromolecules during photosynthesis and nitrogen uptake while store excess iron in ferritin.

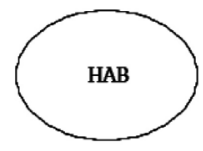

Rapid increase of the algal concentration when all the growth parameters are simultaneously satisfied during the time from sunrise to sunset, whose bloomings at water surface reach the maximum at midday [4].

Figure 10. Conceptual stepwise diagram of iron utilization prior to algal blooms [4] [13] [15] [16] [17] [31] [32] [35] [36]. 
oxidoreductase, ferric reductase, 3) Iron-reducing bacteria, 4) Photochemical, superoxide, humic acid and fulvic acid in peat. It was thus recommended to eliminate $\mathrm{Fe}$ by not only blocking $\mathrm{Fe}^{3+}$ conversion to $\mathrm{Fe}^{2+}$ but also adding sulfur compounds $(\mathrm{S})$ to induce the sedimentary iron sulfides $\left(\mathrm{FeS} / \mathrm{FeS}_{2}\right)$ for suppression of HAB.

As shown in Figure 11, algae utilize the dissolved iron, $\mathrm{Fe}_{(\text {aq })}^{2+}$ in competition with insoluble $\mathrm{FeS} / \mathrm{FeS}_{2}$, the latter being significant if the volcanic activity is stronger for the sulfur compounds ( $\mathrm{S}$ ) than the desert contribution for iron $(\mathrm{Fe})$.

Soluble Fe sulfates in Figure 11 are $\mathrm{FeSO}_{4},(\mathrm{Fe})_{2}\left(\mathrm{SO}_{4}\right)_{3},\left(\mathrm{NH}_{4}\right)_{2} \mathrm{Fe}\left(\mathrm{SO}_{4}\right)_{2}$ and insoluble iron sulfides are $\mathrm{FeS}$ and $\mathrm{FeS}_{2}$, while soluble non-Fe sulfates are $\mathrm{Al}_{2}\left(\mathrm{SO}_{4}\right)_{3}, \mathrm{NH}_{4} \mathrm{HSO}_{4},\left(\mathrm{NH}_{4}\right)_{2} \mathrm{SO}_{4},\left(\mathrm{NH}_{4}\right)_{2} \mathrm{SO}_{3}, \mathrm{BeSO}_{4}, \mathrm{CdSO}_{4}, \mathrm{CuSO}_{4}, \mathrm{MgSO}_{4}$, $\mathrm{MnSO}_{4}, \mathrm{NiSO}_{4}, \mathrm{KHSO}_{4}, \mathrm{~Pb}_{2} \mathrm{SO}_{4}, \mathrm{Na}_{2} \mathrm{SO}_{4}$ and $\mathrm{NaS}_{2} \mathrm{O}_{3}$. Insoluble non-Fe sulfates are $\mathrm{Ag}_{2} \mathrm{SO}_{4}, \mathrm{BaSO}_{4}, \mathrm{PbSO}_{4}, \mathrm{Hg}_{2} \mathrm{SO}_{4}, \mathrm{RdSO}_{4}$ and $\mathrm{SrSO}_{4}$, while soluble sulfide is $\mathrm{H}_{2} \mathrm{~S}$ and insoluble sulfides are $\mathrm{CdS}, \mathrm{CuS}, \mathrm{PbS}$ and $\mathrm{PoS}$.

It is important to eliminate the dissolved iron, $\mathrm{Fe}_{(\mathrm{aq})}^{2+}$, with soluble sulfur compounds $(\mathrm{S})$ to induce insoluble iron sulfides $\left(\mathrm{FeS} / \mathrm{FeS}_{2}\right)$ for suppression of HAB.

The stimulation of diatom growth by Fe addition and the relative abundance of dinoflagellates in Fe limited waters, suggested Fe availability played a key role in the development of HAB [32]. The bioavailable Fe to microorganisms was present in dissolved organic or inorganic, colloidal, and particulate forms, as extensively reviewed by Shaked [17].

Photosynthesis takes place in chloroplast to capture light energy, whose principal photoreceptor is chlorophyll-a with molecular formula of $\mathrm{C}_{55} \mathrm{H}_{68} \mathrm{O}_{5} \mathrm{~N}_{4}$ $\mathrm{Mg}$. The number of nitrogen atoms is thus four per molecule of chlorophyll-a, which requires four $\mathrm{NH}_{4}^{+}$ions to be synthesized to chlorophyll by nitrogen reductase. Since $14 \mathrm{Fe}$ atoms are necessary during the process of photosystem and 32 to $36 \mathrm{Fe}$ atoms are required [4] to activate nitrate reductase during $\mathrm{N}_{2}$ fixation (Figure 12), it is thus, $(14 \times 4)+(32 \sim 36)=88 \sim 92$ Fe atoms can be minimally necessary for the biosynthesis of a molecule of chlorophyll-a. Each photosynthetic cell contains 40 - 200 chloroplasts while each chloroplast has grana

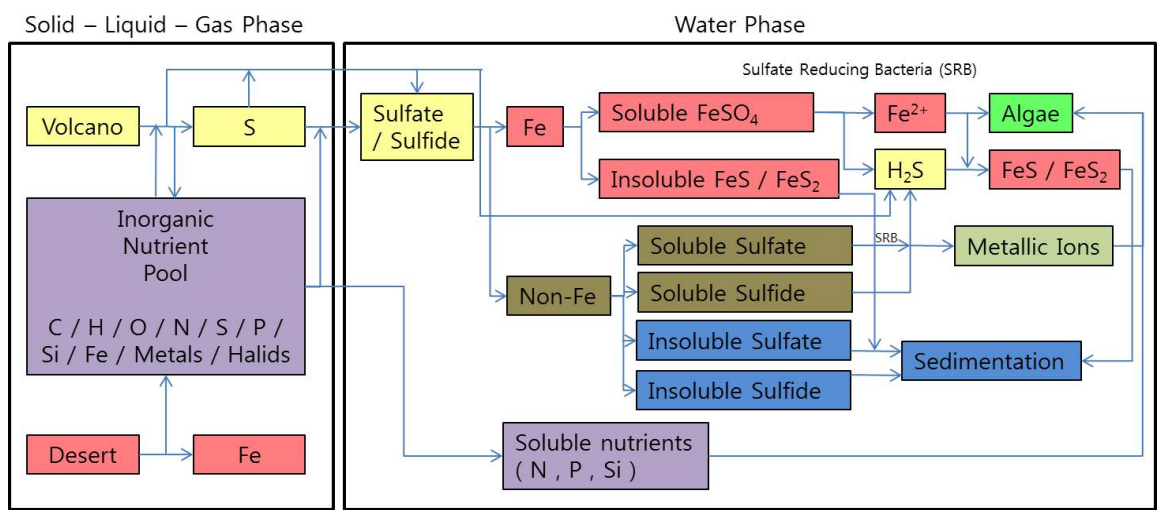

Figure 11. Flow diagram for algal utilization of nutrients, iron, and metallic ions from desert dust and volcano in various phases. 


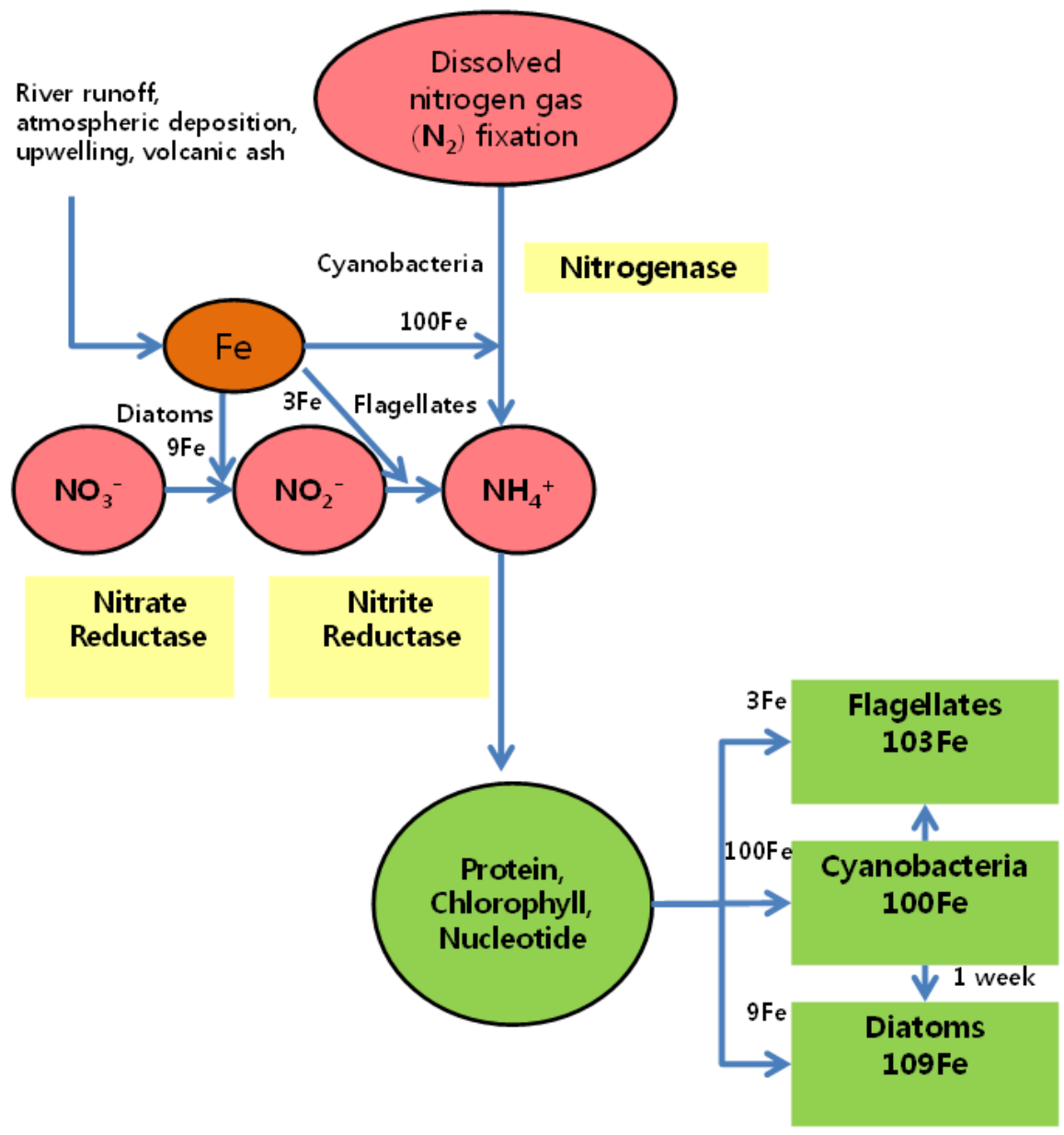

Figure 12. Relative uptake percentage of required Fe for the syntheses of cyanobacteria, diatoms, and flagellates with corresponding nitrogen enzymes while cyanobacteria as main source of Fe were preyed by flagellates and diatoms.

containing $10-20$ thylakoid and thylakoid membrane is covered with 300 chlorophylls [37].

It is expected that each photosynthetic cell contains $1.2 \times 10^{5}-1.2 \times 10^{6}$ chlorophylls to be approximated that each photosynthetic cell of algae requires $\mathrm{Fe}$ atoms as much as: $(88-92 \mathrm{Fe}$ atoms/chlorophyll-a $) \times\left(1.2 \times 10^{5}-1.2 \times 10^{6}\right.$ chlorophyll-a/algae cell) $=1 \times 10^{7}-1 \times 10^{8} \mathrm{Fe}$ atoms/algae cell, which can be close to experimental observation of intracellular Fe quota for Synechococcus spp of $\sim 10^{-18} \mathrm{~mol} /$ cell [38] $\left(\sim 1 \times 10^{6} \mathrm{Fe}\right.$ atoms/cell $)$. Since the algal concentration is in the range of $10^{6}$ cells/ml during algal blooms [39], the resultant Fe atom concentration (atoms $/ \mathrm{ml})$ can be $1 \times 10^{13}-1 \times 10^{14}(\mathrm{Fe}$ atoms $/ \mathrm{ml})$. If the blooming patch is assumed to be 100 meter long, 100 meter wide and 1 meter deep during photosynthesis, its volume can be $10^{4} \mathrm{~m}^{3}$ or $10^{7}$ liter. Thus, Fe atoms in such a volume can be $1 \times 10^{23}-1 \times 10^{24} \mathrm{Fe}$ atoms during HAB. Besides, one mole of iron is $55.8 \mathrm{~g}$ with $6 \times 10^{23}$ atoms, the corresponding Fe concentration is 0.001 $0.01 \mathrm{ppm}\left\{=\frac{\left(1 \times 10^{23} \sim 1 \times 10^{24}\right)\left(55.8 \times 10^{3} \mathrm{mg}\right)}{6 \times 10^{23}\left(10^{7} \mathrm{l}\right)}\right\}$, which can be a comparable 
concentration with $0.0034 \mathrm{ppm}(\mathrm{mg} / \mathrm{l})$ in seawater [40] and $0.3 \mathrm{ppm}$ in drinking water. It is expected that Fe ion either in the seawater or in the freshwater can be minimally satisfied to synthesize only chlorophyll-a containing algae cells although much more Fe can be required further for protein and cellular reproduction during $\mathrm{HAB}$.

As a result of $\mathrm{Fe}$ oxidation to low-solubility compounds and precipitation of Fe with sulfide, $(\mathrm{FeS})$, and phosphorus, $\left(\mathrm{FePO}_{4}\right)$, dissolved Fe levels decreased in coastal oceans with sulfate $\left(\mathrm{SO}_{4}^{2-}\right)$ and phosphate $\left(\mathrm{PO}_{4}^{2-}\right)$ where dissolved $\mathrm{Fe}$ is received from river discharges. In addition, Fe released from the sediments may rise to the surface, along with other minerals. Also, winds carry Fe-rich dust into the oceans from continental land masses, and this dust provides a source of $\mathrm{Fe}$ to algae. For example, the cyanobacterium Trichodesmium is abundant in the Arabian and Caribbean seas and the Indian Ocean because it is able to capture Fe from dust entering such waters. When Fe is relatively abundant, some algae can store it in ferritin, an Fe-storage protein with $1800 \mathrm{Fe}$ and $640 \mathrm{P}$ per molecule [41]. Kawaguchi [42] have proposed bioavailable Fe as an indicator of ecosystem health in the southeastern USA. Ingle [43] predicted the Florida red tide (dinoflagellate blooms) by means of the Fe index. Alderkamp [44] showed that Fe from melting glaciers fueled phytoplankton blooms in the Antarctic. Langroudi [45] cultured algae of Tetraselmis suecica to see that the amount of Fe for its maximum growth was $0.3 \mathrm{ppm}$ while less than $1 \%$ of soluble $\mathrm{Fe}(0.05 \mathrm{ppm})$ was observed in a Australian creek out of total Fe (43 ppm) [15].

Since the structural formula of chlorophyll- $a$ is $\mathrm{C}_{55} \mathrm{H}_{68} \mathrm{O}_{5} \mathrm{~N}_{4} \mathrm{Mg}$, the most limiting nutrient out of $\mathrm{C}, \mathrm{H}, \mathrm{O}, \mathrm{N}$ can be the nitrogen while the oxygen is abundant in the water. However, since algal $\mathrm{N}_{2}$ fixation and $\mathrm{N}$ (specifically nitrate and nitrite) require an abundant supply of $\mathrm{Fe}^{2+}$ (Figure 12), $\mathrm{HAB}$ can occur only if $\mathrm{Fe}$ in $\mathrm{Fe}^{2+}$ is fully available for the abrupt cell growth, expressed by the spontaneous increase of the concentration of chlorophyll-a during the exponential growth phase of the algae. In many cases, estuarine HAB have been linked to terrestrial run-off, following periods of heavy rainfall [15].

Since dissolved Fe levels decreased by six to seven orders of magnitude due to the formation of low-soluble $\mathrm{FeS}$ and $\mathrm{FePO}_{4}$ in waters, most of the delivered $\mathrm{Fe}$ by the Asian dust $(60,000-120,000 \mathrm{ppm})$ can be mainly precipitated to the sediments, since $\mathrm{Fe}$ in freshwater is only $0.3 \mathrm{ppm}$ and $\mathrm{Fe}$ in seawater is barely $0.0034 \mathrm{ppm}$. Therefore, it can be expected that Fe utilization rate by algae is regulated by the release of $\mathrm{Fe}^{2+}$ from Fe complex by reduction, whose reaction is the function of the equilibrium constant and thus the absolute temperature of the freshwater and the seawater. This temperature dependence may be the reason why there is no $\mathrm{HAB}$ during the cold season of winter.

Table 3 implied that $\mathrm{HAB}$ occurred in August after 4 to 5 weeks of heavy rainfall, exceeding the average $103 \mathrm{~mm}$ rainfall on one day in July. Since the cyanobacterial growth in the middle of water was commonly observed a week earlier than the onset of $\mathrm{HAB}$, it could be postulated that the algal growth took about 4 weeks during the lag phase of growth while about one week for the late 
Table 3. Harmful algal blooms in freshwater and seawater in South Korea during the years from 2001 to 2012.

\begin{tabular}{|c|c|c|c|c|c|c|c|c|}
\hline \multirow{4}{*}{ Year } & \multicolumn{8}{|c|}{ Harmful Algal Blooms } \\
\hline & \multicolumn{4}{|c|}{ Freshwater } & \multicolumn{4}{|c|}{ Seawater } \\
\hline & \multicolumn{4}{|c|}{ Daechung Lake, Daejeon City } & \multicolumn{4}{|c|}{ Naro Island, Goheung County } \\
\hline & $\begin{array}{l}\text { Onset } \\
\text { Date }\end{array}$ & $\begin{array}{l}\text { Duration } \\
\text { (day) }\end{array}$ & Species & $\begin{array}{c}\text { Heavy Rainfall } \\
\text { Date/Precipitation } \\
(\mathrm{mm})\end{array}$ & $\begin{array}{l}\text { Onset } \\
\text { Date }\end{array}$ & $\begin{array}{l}\text { Duration } \\
\text { (day) }\end{array}$ & Species & $\begin{array}{c}\text { Heavy Rainfall } \\
\text { Date/Precipitation }(\mathrm{mm})\end{array}$ \\
\hline 2001 & 9.1 & 35 & Microcystis & $7.21 / 61$ & 8.14 & 41 & Cochlonidium & $7.5 / 119$ \\
\hline 2002 & 9.19 & 16 & Microcystis & $8.6 / 175$ & 8.2 & 57 & Cochlonidium & $7.2 / 117$ \\
\hline 2003 & 9.9 & 39 & Microcystis & $7.9 / 155$ & 8.13 & 62 & Cochlonidium & $7.3 / 59$ \\
\hline 2004 & 9.3 & 14 & Oscillatoria & $7.16 / 131$ & 8.5 & 30 & Cochlonidium & $8.22 / 86$ \\
\hline 2005 & 8.2 & 67 & $\begin{array}{c}\text { Microcystisl } \\
\text { Anabaena }\end{array}$ & $7.11 / 178$ & 7.19 & 58 & Cochlonidium & $6.10 / 88$ \\
\hline 2006 & 8.4 & 62 & Anabaena & $7.12 / 49$ & 8.6 & 36 & Cochlonidium & $7.10 / 151$ \\
\hline 2007 & 10.6 & 14 & $\begin{array}{c}\text { Aphanizomenon/ } \\
\text { Microcystis }\end{array}$ & $7.10 / 63$ & 7.31 & 50 & Cochlonidium & $7.1 / 108$ \\
\hline 2008 & 7.25 & 15 & Anabaena & $6.18 / 81$ & 7.30 & 62 & Cochlonidium & $6.1 / 70$ \\
\hline 2009 & 8.6 & 15 & Microcystis & $7.9 / 88$ & 10.28 & 17 & Cochlonidium & $7.7 / 164$ \\
\hline 2010 & 9.2 & 43 & Aphanizomenon & $7.17 / 71$ & 9.17 & 3 & Cochlonidium & $7.16 / 64$ \\
\hline 2011 & 8.12 & 57 & $\begin{array}{c}\text { Oscillatorial } \\
\text { Aphanizomenon }\end{array}$ & $7.8 / 85$ & - & - & - & $5.11 / 92$ \\
\hline 2012 & 9.6 & 63 & $\begin{array}{c}\text { Microcystisl } \\
\text { Aphanizomenon }\end{array}$ & $7.15 / 111$ & 7.27 & 75 & Cochlonidium & $7.11 / 119$ \\
\hline Average & 8.28 & 37 & $\begin{array}{c}\text { Microcystis (7)/ } \\
\text { Oscillatoria (2)/ } \\
\text { Anabaena (3)/ } \\
\text { Aphanizomenon (4) }\end{array}$ & $7.13 / 104$ & 8.12 & 45 & Cochlonidium & $7.4 / 103$ \\
\hline
\end{tabular}

log phase of growth, after which it reached the stationary phase forming large surface algal aggregations of HAB. It was known that the required time for the algal reproduction was 6 hours for diatom under no turbulence. Since the bacterial conversion of $\mathrm{Fe}^{3+}$ to $\mathrm{Fe}^{2+}$ took 15 hours [16] and the photosynthesis was maximized during the 6 hours from dawn (6 AM) to midday (12 PM) [4], the resultant summation $(6+15+6)$ hours were 27 hours for HAB by diatom, which was in accordance with other studies [24] indicating HAB by diatoms after strong winds of a day or two in the sunlit surface waters.

\subsection{Nutrients}

The fundamental solution for the demise of $\mathrm{HAB}$ was to reduce the nutrients in the form of organic materials. Perhaps the most contentious explanation has been the idea that run-off from land was a major contributor to HAB. When managers released water from the massive inland reservoir as a flood-control measure during heavy rains, the nutrient-rich water has been diverted to the river and on to the sea, laden with nutrient pollution from the cities and farms 
[8] [15]. Typical sources of nutrients for algal growth are carbon, nitrogen, phosphorus, sulfur, silicon, and minerals while hydrogen and oxygen are always available within the cell in the form of water to support the cell structure for metabolic functions.

\section{Carbon:}

Carbon in the earth's atmosphere exists in two main forms: carbon dioxide and methane. The terrestrial biosphere includes the organic carbon in all land-living organisms, both alive and dead, as well as carbon stored in soils. Once organisms die, bacteria break down their tissues, releasing $\mathrm{CO}_{2}$ back into the atmosphere or into the soil. $\mathrm{CO}_{2}$ dissolves in the water and algae while plants and bacteria convert it into organic carbon. Their tissues are ultimately broken down by bacteria and $\mathrm{CO}_{2}$ is released back into the ocean or atmosphere. Much of the carbon in the earth's lithosphere (about $80 \%$ ) is stored in limestone, which was formed from the calcium carbonate from the shells of marine animals.

\section{Nitrogen:}

Algae require combined nitrogen to synthesize amino acids, nucleic acids, chlorophyll, and toxins [45]. Nitrogen sources commonly used by cyanobacteria include ammonium, nitrate, nitrite, urea and atmospheric $\mathrm{N}_{2}$, as summarized in Figure 12. Nitrate reductase is membrane-bound while nitrite reductase is both a membrane-bound and a cytoplasmatic enzyme. About $94 \%$ of the oceanic $\mathrm{N}$ inventory exists as biologically unavailable dissolved nitrogen gas $\left(\mathrm{N}_{2}\right)$, which can be made bioavailable through $\mathrm{N}_{2}$-fixation using Fe-dependent nitrogenase for reduction of $\mathrm{N}_{2}$ to $\mathrm{NH}_{4}^{+}$. The $6 \%$ of biologically available $\mathrm{N}$ exists primarily as $\mathrm{NO}_{3}^{-}(\sim 88 \%)$ and dissolved organic nitrogen (DON, $\left.\sim 11.7 \%\right)$. The remaining $0.3 \%$ is found in $\mathrm{NO}_{2}^{-}, \mathrm{NH}_{4}^{+}$, nitrous oxide $\left(\mathrm{N}_{2} \mathrm{O}\right)$ and particulate organic nitrogen (PON) [46]. Dinoflagellates are known to take up substantial amounts of various $\mathrm{N}$ forms in the darkness while diatoms can not. This may be caused by their nitrate reductase preference for anaerobic conditions available in the dark. Nitrogen is generally taken up as dissolved inorganic nitrogen (DIN) : nitrate $\left(\mathrm{NO}_{3}^{-}\right)$, nitrite $\left(\mathrm{NO}_{2}^{-}\right)$and ammonium $\left(\mathrm{NH}_{4}^{+}\right)$. DIN is actively transported across the cell membrane via "uptake sites" and metabolised within the cell to form chlorophyll and amino acids and, in turn, proteins and nucleotides [47]. Since uptake mechanism of DIN across the cell membrane is "active transport", it requires external energy such as $\mathrm{ATP}$ or $\mathrm{NAD}(\mathrm{P}) \mathrm{H}$. The conversion of 1 mole nitrogen to 2 mole ammonia requires 25 moles ATP. Therefore, the nitrogen uptake should be followed by ATP synthesis. The atomic ratio of N/P is commonly known to be $16 / 1$ in freshwater and $176 / 1$ in seawater for HAB. Therefore, nitrogen can be the limiting factor relatively in seawater while phosphorus is the limiting factor in freshwater. This may be why cyanobacterial blooms of $\mathrm{N}_{2}$-fixing Anabaena and Aphanizomenon are common in freshwaters rich in phosphate. Surplus nitrogen is known to be stored in cyanophycin granules and phycobiliproteins [48]. Dinoflagellates might store their $\mathrm{N}$ in the form of uric acid crystals within the cytosol [46]. Although algae typically take up ammo- 
nium or nitrate ions directly from the surrounding water with nitrogen ion of $15.5 \mathrm{ppm}$ [40], some algae obtain ammonium that can be used more directly than nitrate to synthesize cellular N-compounds. Algae are generally able to convert nitrate to ammonium by using the enzyme nitrate reductase, which requires the cofactors $\mathrm{Fe}$ and molybdenum, that are not always present in sufficient amounts because of Fe formation of insoluble precipitate, FeS associated with active undersea volcanoes.

\section{Phosphorus:}

Phosphorus $(\mathrm{P})$ in inorganic phosphate is required during the photosynthesis, as illustrated in Figure 9. Energy stored in the phosphate bonds of ATP generated from photosynthesis is mobilized in the form of biomolecules such as polysaccharides, porphyrins, cellulose, proteins, lipids, RNA, and DNA. These macromolecules biosynthesize cell wall (mucopeptides) and membrane (proteins). Inorganic $\mathrm{P}$ is found in the soil or water. Plants and algae assimilate inorganic $\mathrm{P}$ into their cells, and transfer it to other animals that consume them. When organisms die, their $\mathrm{P}$ is released by decomposer bacteria, which convert organic $\mathrm{P}$ to inorganic $\mathrm{P}$. Aquatic $\mathrm{P}$ follows a seasonal cycle, while inorganic $\mathrm{P}$ peaks in the spring causing rapid algae and plant growth, and then declines. As plants and animals die, organic $\mathrm{P}$ is re-released into the water. $\mathrm{P}$ based fertilizers can cause excessive algae growth in aquatic systems, which can have negative impacts on the environment [22]. In oligotrophic freshwaters, the mineral nutrient that most commonly limits algal growth is P. Blooms of the toxic cyanobacterium Microcystis are common events globally, whose intracellular P pool showed a percentage of total cell-associated P (50\% - 90\%) similar to what has been reported for actively growing algae in marine systems [49]. Surplus phosphate is known to be stored in polyphosphate bodies of cyanobacterial cells [48]. Phosphate levels are usually low in oligotrophic freshwater because this ion readily binds $\mathrm{Al}^{3+}, \mathrm{Fe}^{3+}$, and $\mathrm{Ca}^{2+}$, forming highly insoluble complexes in soils and lake sediments. Schindler [50] showed that eutrophication of lakes was not controlled by reducing nitrogen input but limited by phosphorus input. However, where there is sufficient phosphorus available, biologically available Fe becomes a significant limiting factor of biological growth in oceanic systems as well as coastal and estuarine ecosystems [15]. Jun [51] showed that there were four chemically defined sediment $\mathrm{P}$ such as adsorbed $\mathrm{P}$, non apatite inorganic $\mathrm{P}(\mathrm{NAI}-\mathrm{P})$, apatite $\mathrm{P}$ and residual $\mathrm{P}$ while the release of sediment $\mathrm{P}$ was apparent in the NAI-P rich sediments. The phosphorus in calcium phosphate of apatite $\mathrm{P}$ was released if $\mathrm{pH}$ was low while the phosphorus in $(\mathrm{Fe}+\mathrm{Al})$ complexed NAI-P was released if $\mathrm{pH}$ was high due to the preferred formation of $(\mathrm{Fe}+\mathrm{Al})$ hydroxides. Typically, Figure 13(a) showed the $\mathrm{pH}$ profile of dissolved inorganic phosphate upstream of the Han River in Seoul in Korea. It shows that dissolved inorganic phosphate could be low if $\mathrm{pH}$ in lakes was below 6 while dissolved phosphate levels are relatively high (0.088 ppm), as is in marine waters with $\mathrm{pH}$ of $7.8-8.4$ [40]. An interesting experimental observation was that the level of the dissolved inorganic 


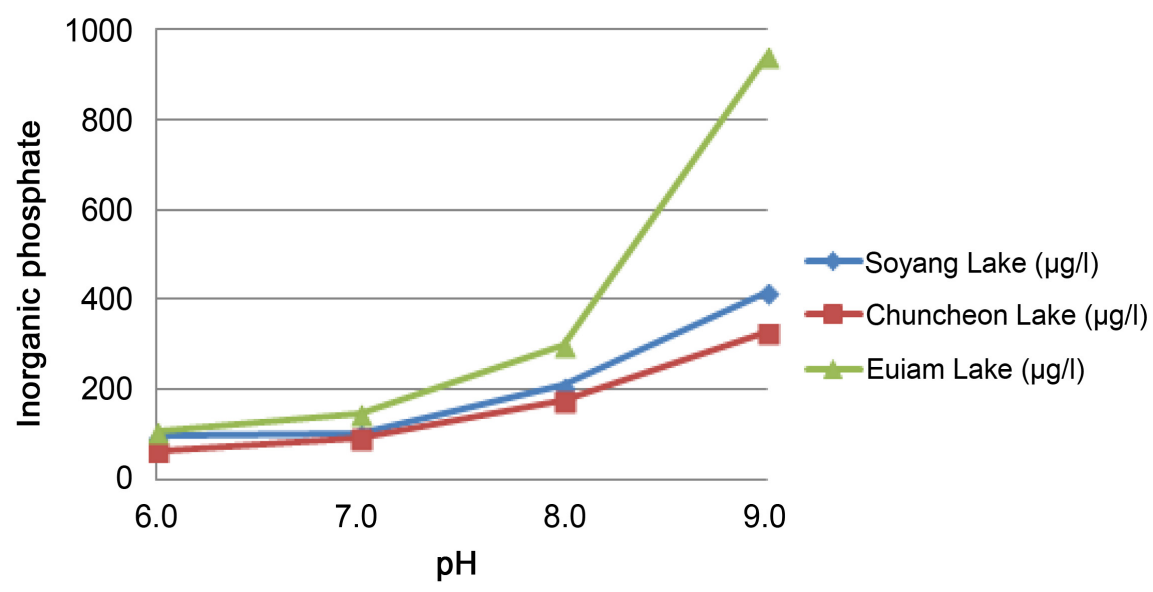

(b)

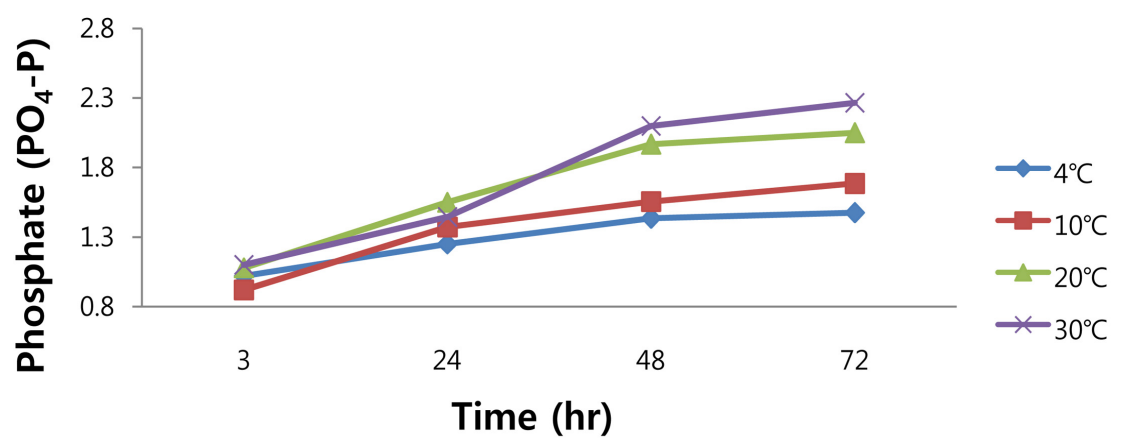

(a)

Figure 13. (a) Distribution of dissolved phosphate with variation of $\mathrm{pH}$ in Korean Lakes redrawn from Jun [51]. (b) Distribution of dissolved phosphate with variation of temperature in the river redrawn from Min [51].

phosphate was decreased if the temperature of freshwater was below $15^{\circ} \mathrm{C}$ [52], as shown in Figure 13(b). It was therefore expected that there could be HAB if freshwater temperature was above $15^{\circ} \mathrm{C}$.

The discharge allowance of phosphorus from the wastewater treatment plant is $0.2 \mathrm{ppm}$ in Korea. In order to reduce the hazard of HAB in the river, one suggestion is to recycle the wastewater for further removal of phosphorus from the discharge water.

When phosphorus becomes so abundant that it no longer limits algal growth in eutrophic lakes, another nutrient (usually nitrogen, though sometimes $\mathrm{Fe}$ ) becomes limiting. Moisander [53] reviewed that phosphorus availability might determine the times and locations for blooms of $\mathrm{N}_{2}$-fixing harmful cyanobacterium Nodularia in the Baltic Sea, Australia, United States, South Africa, and New Zealand although they acknowledged the possibility of other controlling factors such as trace element limitations.

Figure 13(a) showed that dissolved phosphate could be kept minimal if $\mathrm{pH}$ was maintained below 6 . Since phosphate is used as the energy source during biosynthesis of $\mathrm{HAB}$ as shown in Figure 9, $\mathrm{HAB}$ can be prevented by keeping $\mathrm{pH}$ below 6 (Figure 13(a)) and temperature below $15^{\circ} \mathrm{C}$ (Figure 13(b)) for 
prevention of $\mathrm{HAB}$. Since bubbling with pure $\mathrm{CO}_{2}$ gas induced the freshwater with $\mathrm{pH}$ below 4.2, it was easy to suppress $\mathrm{HAB}$ within the small area.

\section{Sulfur:}

Sulfur is an essential element for all life and widely used in biochemical processes. In metabolic reactions, sulfur compounds (S) serve as both fuels and respiratory (oxygen-alternative) materials for simple organisms. The oxidation of sulfide occurs in stages, with inorganic sulfur being stored either inside or outside of the cell until needed. Biochemically, reduced sulfur compounds (S) are converted to sulfite $\left(\mathrm{SO}_{3}^{2-}\right)$ and, subsequently, sulfate $\left(\mathrm{SO}_{4}^{2-}\right.$ ) by the enzyme sulfite oxidase [54]. Metabolic mechanism of sulfur within the very surface of the sediment is as follows, which eventually produces hydrogen sulfide $\left(\mathrm{H}_{2} \mathrm{~S}\right)$.

$$
\begin{gathered}
\left(\mathrm{CH}_{2} \mathrm{O}\right)_{106}+\left(\mathrm{NH}_{3}\right)_{18}\left(\mathrm{H}_{3} \mathrm{PO}_{4}\right)+53 \mathrm{SO}_{4}^{2-} \\
\downarrow \text { sulfate reducing bacteria } \\
53 \mathrm{~S}^{2-}+106 \mathrm{CO}_{2}+\mathrm{H}_{3} \mathrm{PO}_{4}+18 \mathrm{NH}_{3}+106 \mathrm{H}_{2} \mathrm{O}
\end{gathered}
$$

Sulfur is required during the photosynthesis (Table 2) while protein building blocks of amino acids such as cysteine and methionine are composed of sulfur. Marine waters are relatively high $(2701 \mathrm{ppm})$ in sulfate ion $\left(\mathrm{SO}_{4}^{2-}\right)$. Sulfate-reducing bacteria convert sulfate to sulfide ion $\left(\mathrm{S}^{2-}\right)$, which readily combines with $\mathrm{Fe}$ to form an insoluble precipitate, FeS. As a result, less dissolved $\mathrm{Fe}$ is available to react with phosphate, so dissolved phosphate levels remain relatively high $(0.088 \mathrm{ppm})$ in marine waters [40]. Decomposed microorganisms from foodstuff disposal produced $\mathrm{H}_{2} \mathrm{~S}$ gas [9], which could be applied to both of freshwater and seawater to sediment the dissolved Fe as insoluble $\mathrm{FeS}$ and $\mathrm{FeS}_{2}$ for prevention of HAB in Florida's lake and coast, as shown in Figure 14 [2],

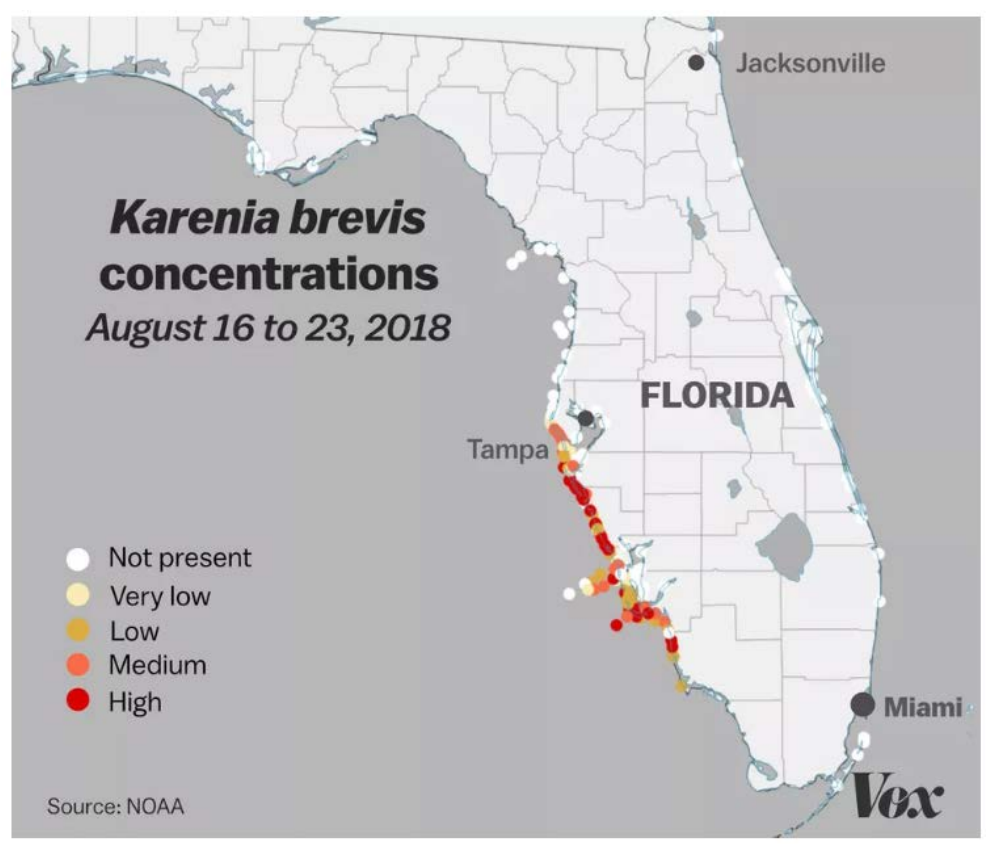

Figure 14. Karenia brevis concentrations in Florida (August 16 to 23, 2018) [2]. 
respectively. Therefore, $\mathrm{HAB}$ could be prevented in freshwater and seawater by sulfur compounds $\left(\mathrm{H}_{2} \mathrm{~S}\right.$, sulfates) inducing the deficiency of the dissolved Fe in the water.

\section{Silicon:}

The Redfield ratio of Si:N:P shows 16:16:1 while China seas (28:4:1), Sea of Japan (36:7:1), Subarctic Pacific (20:9:1), Eastern Equatorial Pacific(6:7:1), which are on the trajectories of the Asian dust [26]. Unlike the majority of other phytoplankton, diatoms utilize silicic acid $\mathrm{Si}(\mathrm{OH})_{4}$, to construct their cell walls and are controlled by its availability and distribution. The ratio of $\mathrm{Si} / \mathrm{Fe}$ in Asian dust [29] was approximately 7 while 182 - 526 in algal cell. Limitation of diatom metabolism by the supply rate of silicic acid results in a physiological cascade that affects diatom primary productivity and nitrogen use, potentially altering regional nitrogen and carbon cycling. Diatoms using silicon to make their shells are important bloom-forming phytoplankton that contribute $\sim 40 \%$ of global ocean productivity [55]. Lippermeier [56] observed that both diatom cell numbers and chlorophyll-a concentration were increased after the addition of $\mathrm{Na}_{2} \mathrm{SiF}_{6}$, which showed the importance of silicate for the photosynthetic performance similar to that of other nutrients like nitrogen, phosphate and iron.

Healey [57] found that chlorophyll-a synthesis of diatom Navicula pelliculosa ceased in 5 to $7 \mathrm{~h}$ of silicon ( $\mathrm{Si}$ ) starvation while Kong [58] observed 6 hours for diatom doubling time. Under ammonium limitation the ratio of silica to chlorophyll-a was 22.7 - 21.0 in Skeletonema costatum [59]. The Weddell Sea has been deemed by scientists to have the clearest water of any sea with a Secchi disc visible at a depth of 79.86 meters (Weddell Sea-Wikipedia, https://en.m.wikipedia.org). The Weddell Sea showed the lowest biogenic silica accumulation rates in the Southern Ocean [60]. Therefore, the clearest water of the Weddell Sea could be induced by the high content of silica. It was thus recommended to spread the silica powder $(\sim 74 \% \mathrm{Si})$ over the water surface prior to the early exponential phase of algal growth for prevention of HAB in freshwater or in seawater.

\section{Minerals:}

Algal growth requires the assimilation of mineral nutrient from the water. Such mineral nutrients (K: 390 ppm, Mg: 1295 ppm, Ca: 416 ppm, Si: 3 ppm, Fe: $0.0034 \mathrm{ppm}, \mathrm{Mn}: 0.0004 \mathrm{ppm}$ in seawater [40]) are commonly taken up by means of transport proteins located in the plasma membrane, though some algae also obtain minerals by engulfing particles such as bacterial cells and picoplankton [28]. Major chemical elements required by green plants are $\mathrm{N}_{2}, \mathrm{P}, \mathrm{K}, \mathrm{S}, \mathrm{Ca}$, and $\mathrm{Mg}$ while minor ones are $\mathrm{Fe}, \mathrm{Cu}, \mathrm{Zn}, \mathrm{Mn}$, and Mo. If molybdenum is deficient in plants, the plant cannot make proteins [61]. Molybdenum in drinking-water has a mean of $0.0859 \mathrm{ppm}$ and a range of $0.003-1.024 \mathrm{ppm}$ in the USA [62] while $0.0105 \mathrm{ppm}$ in seawater [63] and $1.57 \mathrm{ppm}$ in aeolian dust [64]. Combined (fixed) nitrogen, iron, phosphate, and sometimes silica $\left(\mathrm{SiO}_{2}\right)$ are essential nutrients needed by algae in particularly large amounts. The mineral 
nutrients most likely to limit algal growth are important because additions of these minerals are most likely to cause $\mathrm{HAB}$ and other undesirable changes in aquatic systems [34]. Inorganic chemical composition of a typical algal cell is normalized with respect to nitrogen in atomic basis, C/N (6.6/1), Si/N (1/3.3 $1 / 5.7), \mathrm{S} / \mathrm{N}(1 / 10-1 / 20), \mathrm{P} / \mathrm{N}(1 / 16), \mathrm{Mo} / \mathrm{N}$ (1/232 in river - 1/1476 in seawater), and Fe/N (1/600 - 1/3000 in Synechococcus) [65]. Thus, Fe and molybdenum can be limiting factors for algal growth. In order to prevent HAB, it is important to limit mineral ions as primary sources and not secondary ones.

\subsection{Environmental Factor}

Water quality parameters and meteorological conditions influencing $\mathrm{HAB}$, have been extensively studied by many investigators [4] [33] [53]. Growth factors for HAB are summarized in Table 4 while important parameters were stepwise discussed as below.

\subsubsection{Current}

Currents are unidirectional water flows that are strongly influenced by winds and coastal topography, which bring a constant supply of inorganic nutrients to algae. Figure 15 shows the area where in-land algal blooms in rivers or lakes have occurred with animal damage by harmful cyanobacteria such as Anabaena, Aphanizomenon, Microcystis, Nodularia, Nostoc, Oscillatoria with toxins of Anatoxin-a (Anabaena), Microcystin (Microcystis), and Nodularin (Nodularia) [66]. Moisander [53] concluded that phosphorus availability may determine the times and locations for blooms of $\mathrm{N}_{2}$-fixing harmful cyanobacterium Nodularia in the Baltic Sea, Australia, United States, South Africa, and New Zealand although they acknowledged the possibility of other controlling factors such as trace element limitations. Hallegraeff [45] studied the transport of toxic dinoflagellate cysts via ship's ballast water to explain not only the apparent global increase in the geographic distribution of paralytic shellfish poisoning but also the distribution of Australian ports with establishment of toxic dinoflagellate populations. Although the ballast water can be one of the causes of HAB, it may not explain the global in-land $\mathrm{HAB}$ where there are no port and the water streamline is not inwards to the land but outwards to the coast. It is important to consider the facts that major aeolian dust events arise from the Sahara and Sahel deserts ("African dust"), the Australian deserts ("Australian dust") and the Taklamakan and Gobi deserts, the Loess plateau, and the northern India and Bangladesh

Table 4. Growth factors for HAB in physical, chemical and biological processes.

\begin{tabular}{cc}
\hline Process & Growth Factors for HAB \\
\hline Physical & Current, Upwelling, Temperature, Light, Tubulence, Rainfall, \\
Chemical & Nutrients, pH, Dissolved Oxygen \\
Biological & Cyst, Food web, Growth phase, Algae size, Enzyme \\
\hline
\end{tabular}




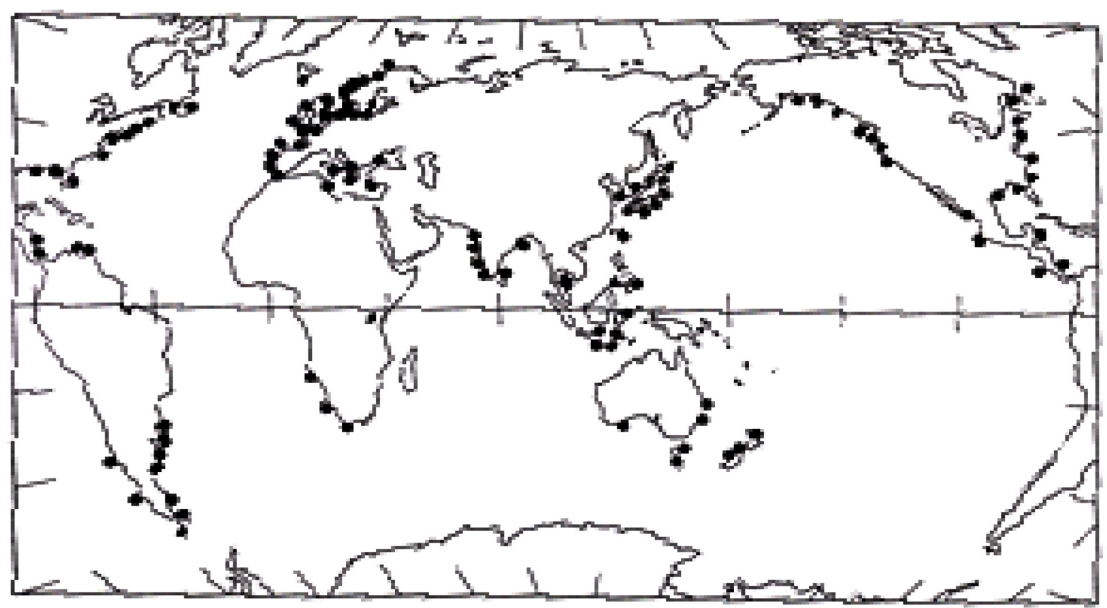

(a)

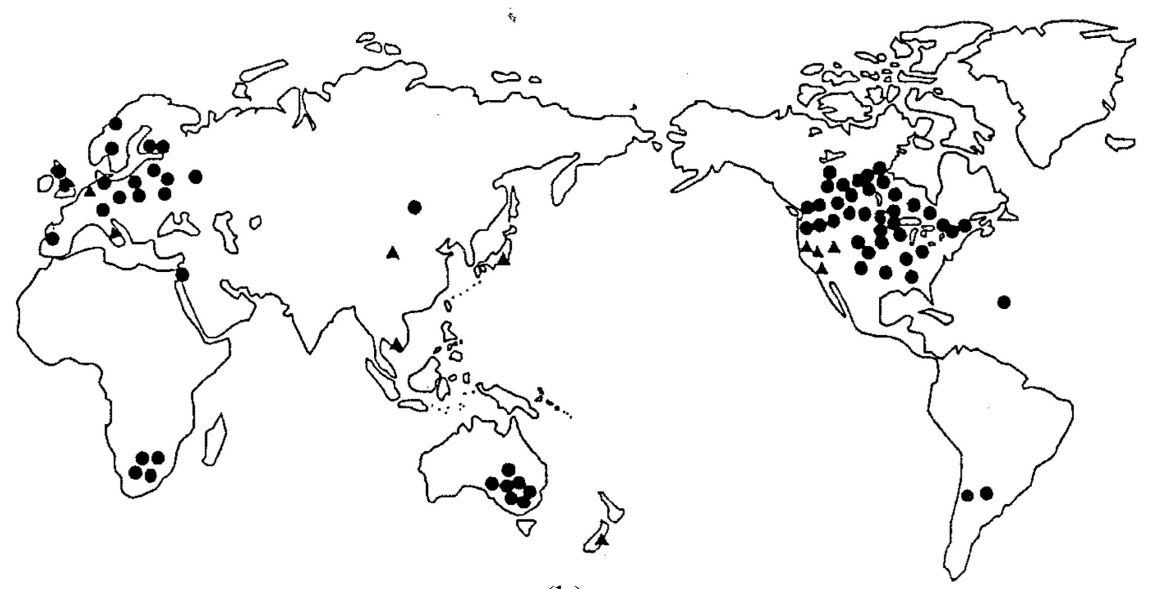

(b)

Figure 15. (a) Global distribution of red tide occurrence, (b) Global distribution of harmful cyanobacterial bloom occurrence country where the animal damage ( $)$ and the occurrence $(\boldsymbol{\Delta})$ were reported by Watanabe [67].

(“Asian dust”). Figure 15(a) (Global red tide occurrence region) and Figure 15(b) (Global harmful cyanobacterial blooms occurrence country) show that aeolian dusts carry the micronutrients in the atmosphere or by oceanic currents to cause global HAB in both on the coast (Figure 15(a)) and in-land (Figure 15(b)).

\subsection{2. $\mathrm{pH}$}

Abundance of cyanobacteria as a function of $\mathrm{pH}$ was shown in various rice soils from India [68] in Figure 16. Cyanobacteria had the maximal growth at a $\mathrm{pH}$ of 7.15. Therefore, cyanobacteria growth can be retarded if $\mathrm{pH}<5$ or $\mathrm{pH}>10$ as less as 1000 folds from $10^{8}$ units/g soil to $10^{5}$ units/g soil. Low $\mathrm{pH} 5$ can be achieved by bubbling atmospheric air with $\mathrm{CO}_{2}$ of about $400 \mathrm{ppm}$ or pure $\mathrm{CO}_{2}$ gas for fast response. There are $\mathrm{CO}_{2}$ gas tanks in every drinking water purification plant to adjust the $\mathrm{pH}$ of alminium sulfate, $\mathrm{Al}_{2}\left(\mathrm{SO}_{4}\right)_{3}$, as a coagulating agent in the purification of drinking water. High $\mathrm{pH} 10$ can be reached by caustic soda 


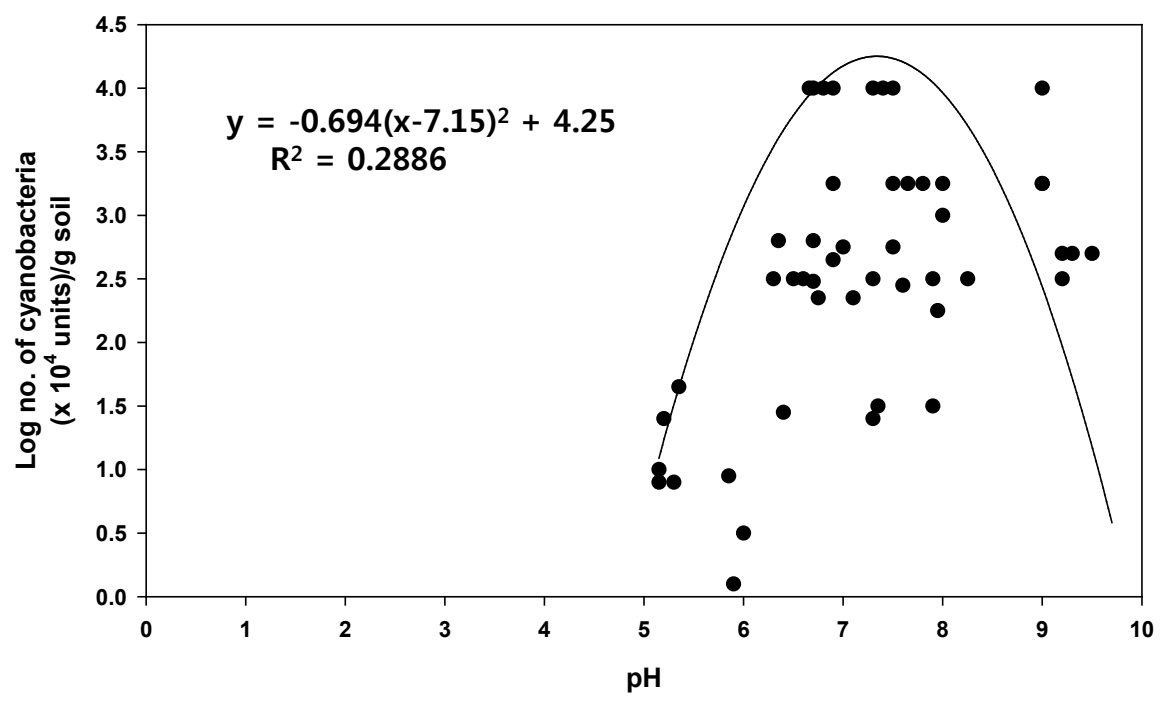

Figure 16. Abundance of cyanobacteria as a function of $\mathrm{pH}$ in various rice soils from India (redrawn and correlated from Nayak [68]).

$(\mathrm{NaOH})$ with dilution of more than 1000 folds. Since algal growth is strongly dependent upon $\mathrm{pH}$, it is possible to prevent $\mathrm{HAB}$ in the freshwater by $\mathrm{pH}$ adjustment, especially during the early growth phase with a small blooming area.

Figure 17 showed the algal growth curves in the seawater with various $\mathrm{pH}$ in the bench scale. The least cell growth was observed at $\mathrm{pH}$ of 5 and 6 although it was impossible to adjust the $\mathrm{pH}$ of seawater in the field.

\subsubsection{Temperature and Salinity}

Since temperature promotes the enzymatic activity of algal, temperature is an important parameter to prevent $\mathrm{HAB}$ in freshwater and seawater. From 2010 to 2012 the Han River in Korea showed HAB when water temperature was greater than $25^{\circ} \mathrm{C}$. On the other hand $\mathrm{HAB}$ induced by $C$. polykrikoides showed the reduced cell growth curve when the seawater temperature was less than $10^{\circ} \mathrm{C}$, as seen in Figure 18 \& Figure 19. Stable stratification with thermocline induced $\mathrm{HAB}$ in the seawater [58]. Low salinity did not extensively decrease the growth of $C$. polykrikoides. HAB in the seawater after the heavy rainfall (Table 2) could be associated with bulk inputs of nutrient, iron, nitrogen, and minerals, run-off from land by heavy rainfall into the sea. Diluted salinity of seawater after the heavy rainfall might not be the main reason of $\mathrm{HAB}$ in the seawater.

\subsubsection{Dissolved Oxygen}

In aquatic systemes, the concentration of dissolved oxygen (DO) is related to water temperature and the speed at which the water moves.

Mass balance DO in the water is given by,

$$
\frac{\mathrm{d} m}{\mathrm{~d} t}=(\dot{m})_{\text {in }}-(\dot{m})_{\text {out }}+(\dot{m})_{\text {gen }}-(\dot{m})_{\text {cons }}
$$

where

$(\dot{m})_{\text {generation }}=$ Oxygen produced by algal photosynthesis as, 


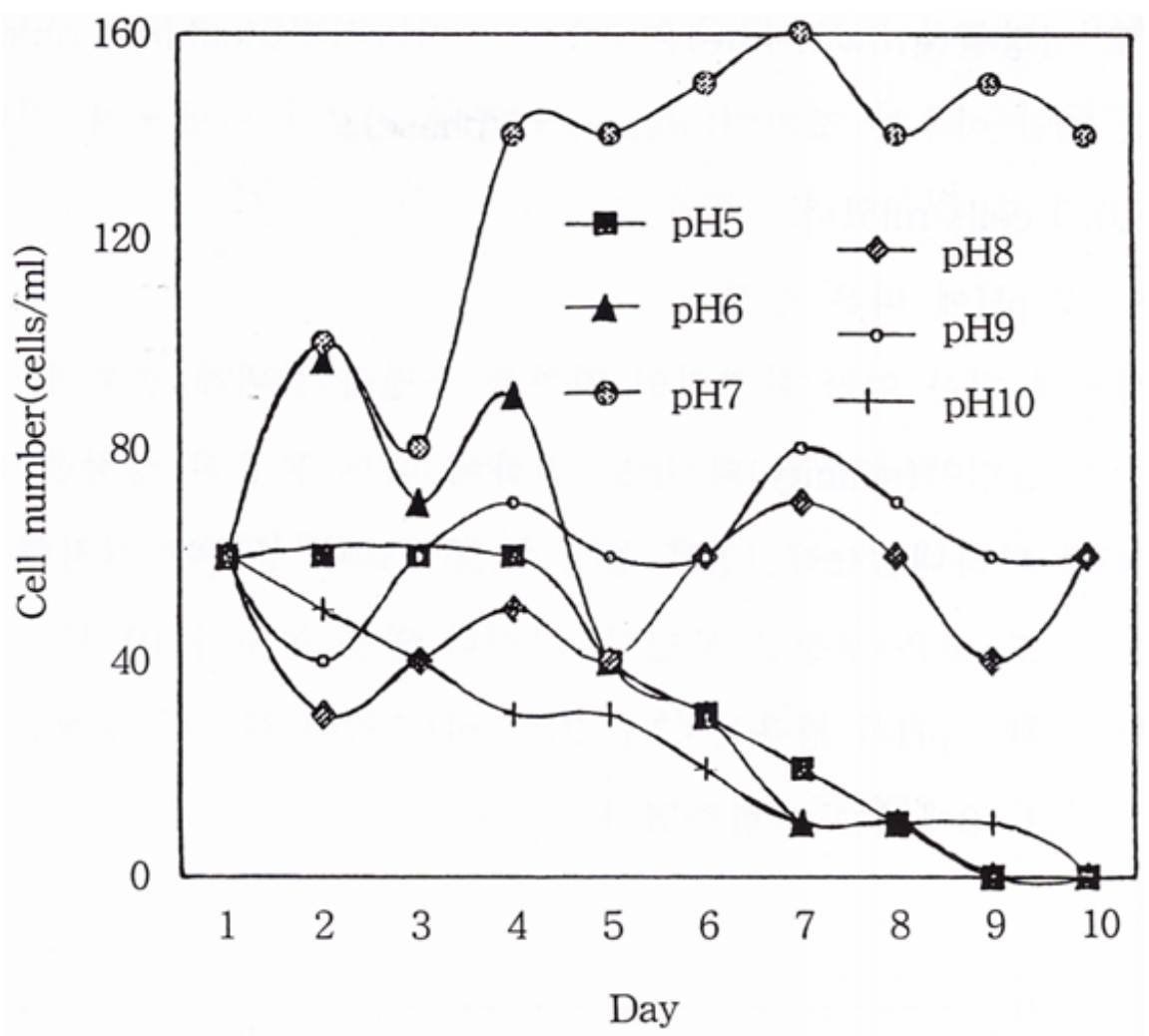

Figure 17. Growth curves of Tamarense with various $\mathrm{pH}$ from National Institute of Fisheries Sciences [69].

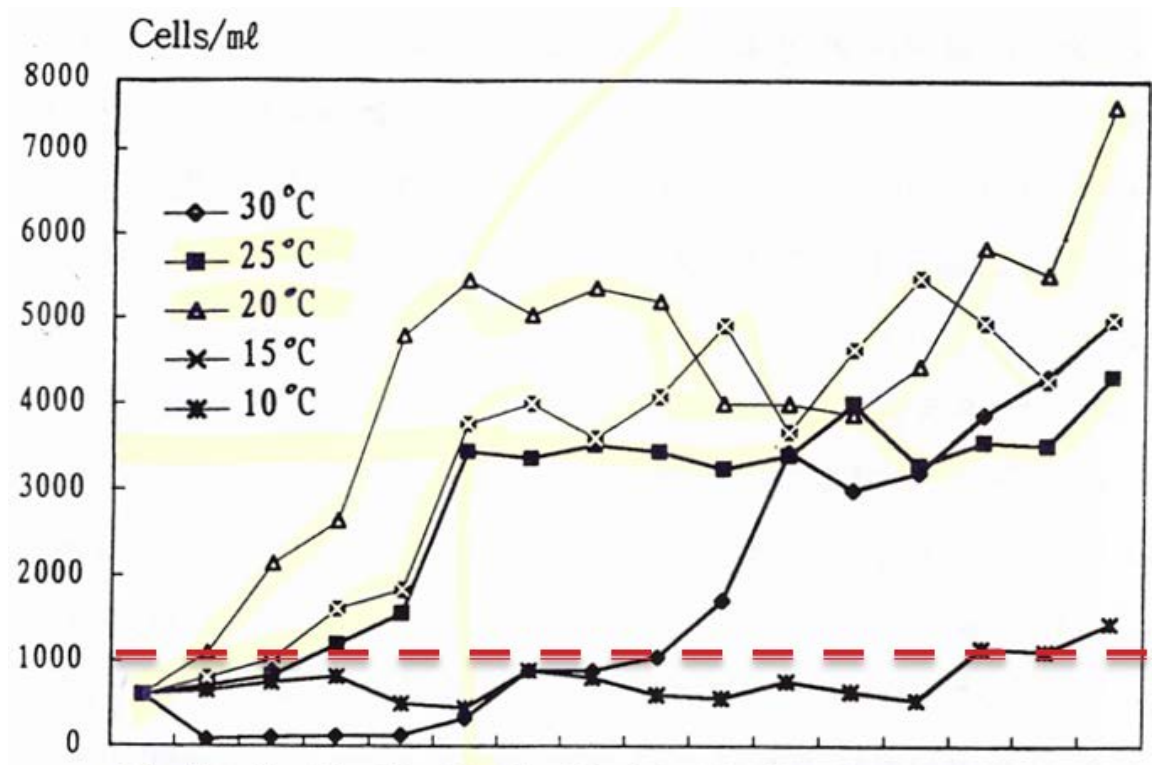

12- $13-14-15-17-20-21-23-24-26-28-30-03-06-13-19-$

Jun Jun Jun Jun Jun Jun Jun Jun Jun Jun Jun Jun Jul Jul Jul Jul

Figure 18. Growth curves of C. polykrikoides at the various temperatures from National Institute of Fisheries Sciences [69].

$$
6 \mathrm{CO}_{2}+6 \mathrm{H}_{2} \mathrm{O} \rightarrow \mathrm{C}_{6} \mathrm{H}_{12} \mathrm{O}_{6}+6 \mathrm{O}_{2}
$$

$(\dot{m})_{\text {consumption1 }}=$ Oxygen consumed by respiration of aerobic microorganism 
as,

$$
6 \mathrm{O}_{2}+\mathrm{C}_{6} \mathrm{H}_{12} \mathrm{O}_{6} \rightarrow 6 \mathrm{CO}_{2}+6 \mathrm{H}_{2} \mathrm{O}+38 \mathrm{ATP}
$$

$(\dot{m})_{\text {consumption } 2}=$ Oxygen consumed by algae and microorganism during biosynthesis,

$$
\mathrm{C}_{6} \mathrm{H}_{12} \mathrm{O}_{6}+\alpha_{1} \mathrm{O}_{2}+\alpha_{2} \mathrm{NH}_{3} \rightarrow \beta_{1} \mathrm{C}_{4.4} \mathrm{H}_{7.3} \mathrm{~N}_{0.86} \mathrm{O}_{1.2}+\beta_{2} \mathrm{CO}_{2}+\beta_{3} \mathrm{H}_{2} \mathrm{O}
$$

Case $1 ;(\dot{m})_{g e n}>(\dot{m})_{\text {cons. }} \frac{\mathrm{d} m}{\mathrm{~d} t}>0 \quad$ O.K.

Case 2; $(\dot{m})_{g e n}<(\dot{m})_{\text {cons }} \frac{\mathrm{d} m}{\mathrm{~d} t}<0$ not O.K. but require external air bubbling

Therefore, $\mathrm{DO}$ is one of the important parameters for $\mathrm{HAB}$ not to suffocate fish.

Water mills and boat turbulence for the enhanced DO can inhibit HAB in freshwater and in seawater.

\subsubsection{Food Web}

Algae play an important role in the aquatic food web, as shown in Figure 20.

Algae growth and reproduction decreased so long as their preys of the particulate or dissolved in organic materials in aquatic system are limited. One of the best ways to prevent $\mathrm{HAB}$ is thus to increase their grazer, lytic bacteria, and virus [28].

\subsubsection{Turbulence}

$\mathrm{HAB}$ was inhibited by shear in the freshwater and in the seawater. Therefore, suitable nutrient, temperature, light, and shear are the initial growth requirements to prevent $\mathrm{HAB}$ [70]. Boat turbulence and water mills on the surfaces of the freshwater (river, lake, reservoir) and the seawater (fish farmery) disturb the water surfaces for turbulence to prevent $\mathrm{HAB}$. Long hydraulic retention time without turbulence or shear induce $\mathrm{HAB}$ in the waters.

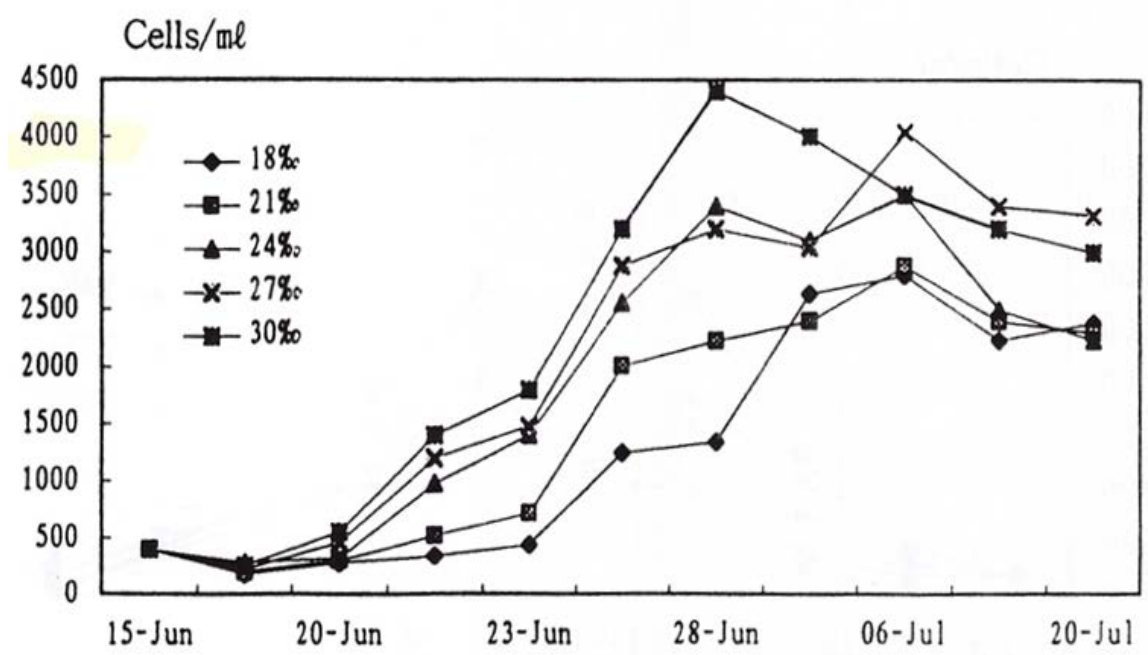

Figure 19. Growth curves of C. polykrikoides at $15^{\circ} \mathrm{C}$ with various salinity of the seawater from National Institute of Fisheries Sciences [69]. 


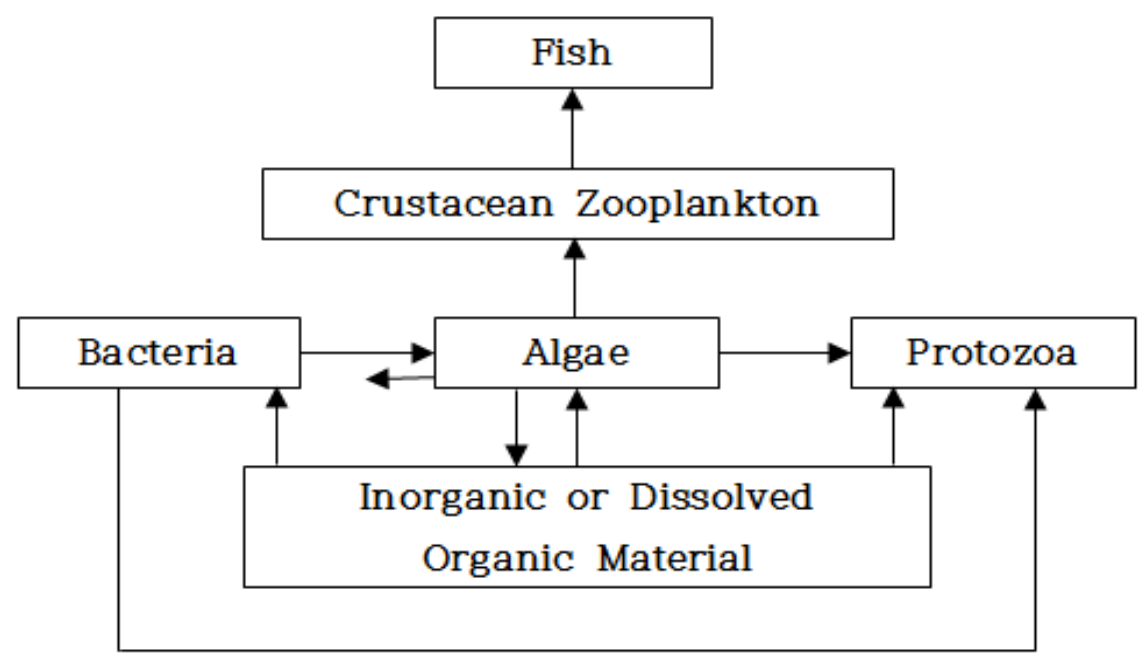

Figure 20. Conceptual diagram of aquatic food webs with algae (redrawn from Graham [14]).

\subsubsection{Enzyme}

Enzymes as protein molecules possess complex structures with a variety of reactive amino acid side chains in enzyme active sites to provide many kinds of catalytic activities. Especially, metal ion requirements for an enzyme are usually specific, with little or no enzyme activity observed if the specified metal ion is absent or if another metal ion is substituted for the natural one. Metal ions such as Fe, magnesium, manganese, cobalt, copper, nickel, molybdenum, zinc, and others are required for enzyme catalytic action. As with the organic cofactors, metal ions are required in only very small amounts, so they are considered essential trace elements or micronutrients. It can be seen that all the biological processes including $\mathrm{HAB}$ can be manipulated by their relevant enzymatic activities with micronutrients of metal ions. Figure 21 shows the schematic flow diagram of HAB with enzymes. Since enzymes accelerate specifically the biosynthesis of macromolecules such as polysaccharides, lipids, and proteins to be made as algal membrane, cell wall, DNA, and RNA, only if the cofactors of mineral ions are available, the initial step of algal growth is fully dependent upon the availability of metal ions. It is thus necessary to keep certain levels of minerals free of aeolian desert dust not only for proper enzymatic reaction at an optimal temperature and $\mathrm{pH}$ but also for algal growth and reproduction during $\mathrm{HAB}$.

\subsubsection{Growth Phase}

The algal growth curve is typically shown in Figure 22(a). It is difficult to determine the timing of the onset of logarithmic growth phase (Figure 22(b)) to prevent $\mathrm{HAB}$.

An index $(\theta)$ was proposed as control parameter of HAB defined as,

$$
\begin{gathered}
\tan \theta=\frac{\mathrm{d} \log n}{\mathrm{~d} t} \\
\theta=\tan ^{-1}\left\{\frac{\mathrm{d} \log n}{\mathrm{~d} t}\right\}
\end{gathered}
$$




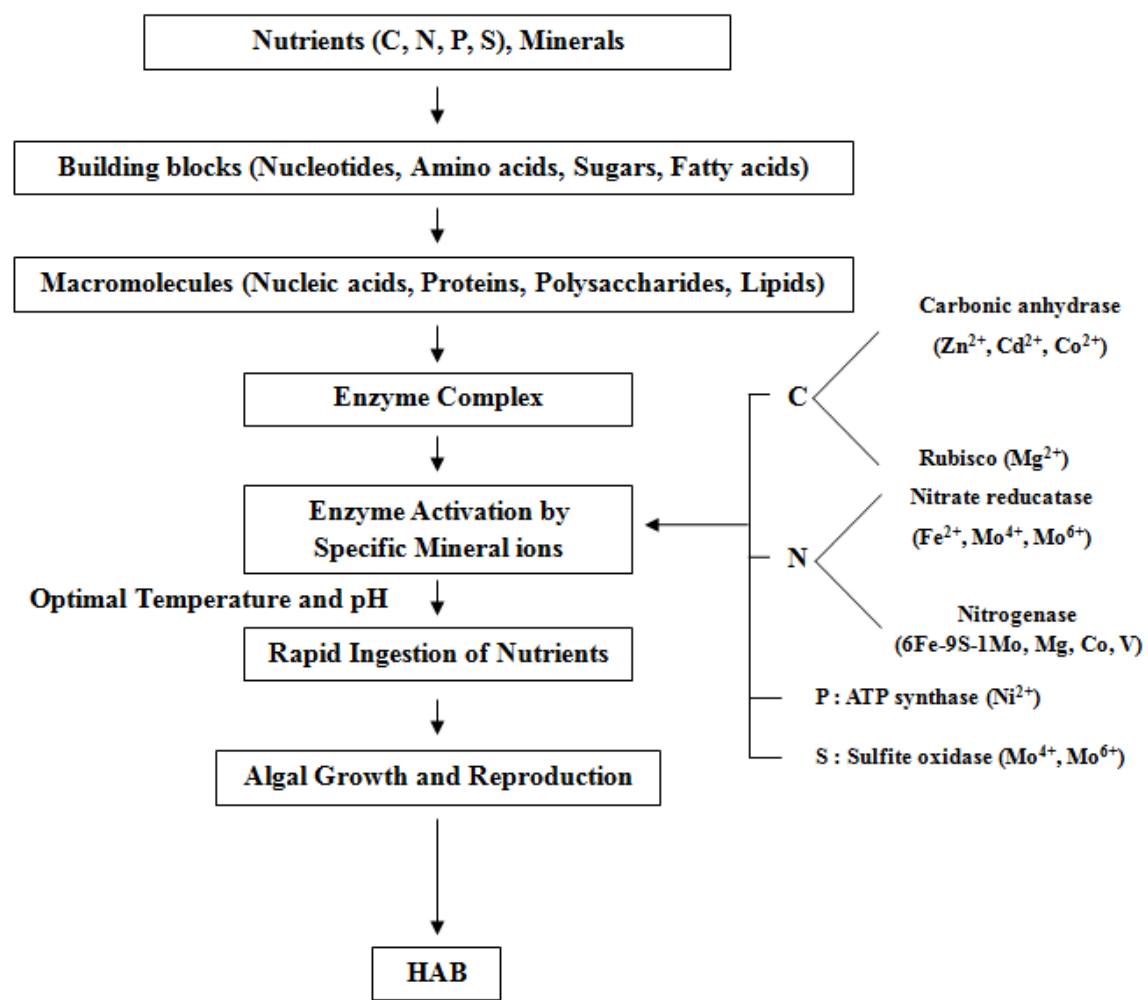

Figure 21. Schematic flow diagram of HAB with enzymes and minerals.

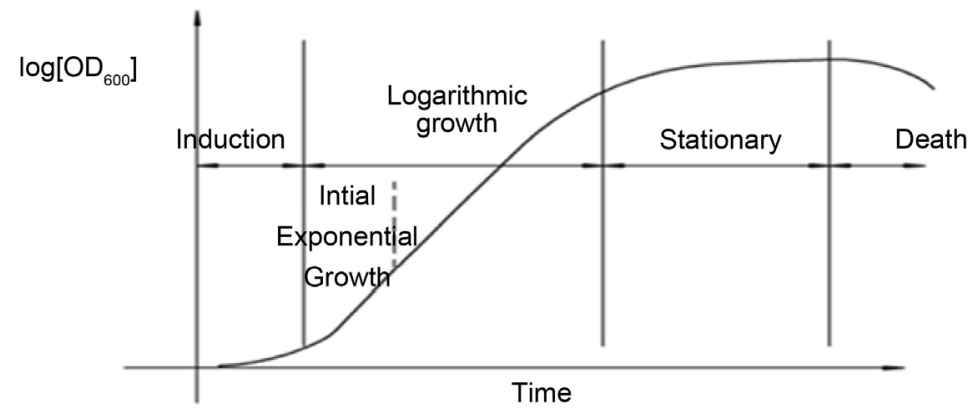

(a)

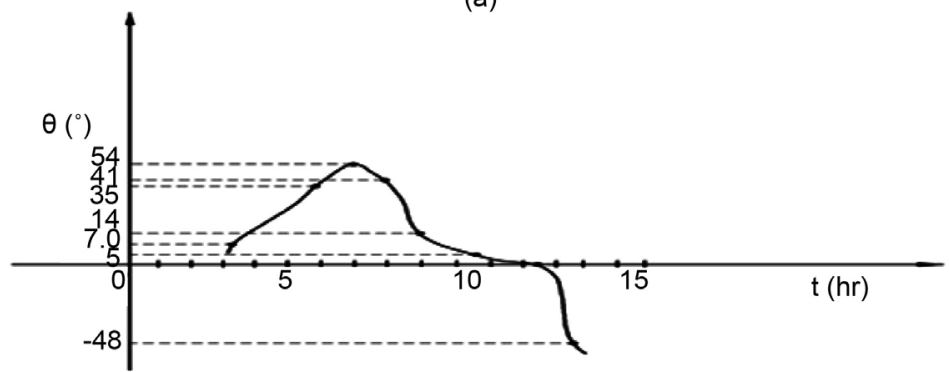

(b)

Figure 22. (a) Algal growth curve for various phases. (b) Determination of the onset time of logarithmic growth phase by index during $\mathrm{HAB}$.

where, $n$ : algal cell concentration (cells $/ \mathrm{ml}), \tan ^{-1}$ : slope of logarithmic algal growth curve $\left(\frac{\mathrm{d} \log n}{\mathrm{~d} t}\right)$, t. time. 
Figure 22(a) is a typical algal growth curve while Figure 22(b) is the index $(\theta)$ for determination of the onset of logarithmic growth phase during HAB. Figure 22(b) indicates that the onset of the logarithmic growth phase begins at the typical index of 7 until 54. It is therefore necessary to suppress HAB before reaching such a maximal index by various control measures of growth factors in Table 4. Therefore, HAB can be prevented if the algal growth is limited by the key parameters prior to reaching the early exponential growth phase, after which the algal toxins are produced to be superior to other competing species and reaching the exponential growth phase and the stationary phase where no further prevention tool is possible and we can only observe the resultant damage of HAB.

\section{Conclusion}

Harmful algal blooms (HAB) were initiated by the iron (Fe) from volcanic ash, river, bottom sediment, and desert dust to be converted as $\mathrm{Fe}_{(\text {aq) }}^{2+}$. The concentration of chlorophyll-a reached the peak value after Fe supply with a lag time of 11 days. It could be possible to predict the outbreak of HAB in both freshwater and seawater so long as the weekly distribution of Fe concentration in the desert dust was available in advance. $\mathrm{HAB}$ occurred in August after 4 to 5 weeks of heavy rainfall, exceeding an average of $103 \mathrm{~mm}$ rainfall in one day of July. Heavy rainfall ran off the nutrient-rich water from the river to the sea with occurrence of $\mathrm{HAB}$ in the seawater. Diluted salinity by heavy rainfall might not be the direct cause of $\mathrm{HAB}$ in the seawater. $\mathrm{HAB}$ could be prevented if the algal growth was limited by the key parameters prior to reaching the early exponential growth phase determined by an index $(\theta)$, after which no outcome is possible except $\mathrm{HAB}$. Seasonal $\mathrm{HAB}$ was predicted by the surface area of algae size associated with the total sunlight energy. As for cyanobacteria, the order of large surface area was Microcystis $>$ Aphanizomenon $>$ Oscillatoria $>$ Anabaena with seasonal $\mathrm{HAB}$ due to various light energy flux. Dissolved inorganic phosphate in lakes was low when $\mathrm{pH}$ was below 6 and temperature below $15^{\circ} \mathrm{C}$ while recycling the wastewater from the urbine wastewater treatment facility was suggested for further removal of phosphorus to reduce $\mathrm{HAB}$ in the river. Boat turbulence and water mills on the surface of the freshwater (river, lake, reservoir) and the seawater (fish farmery) disturbed the occurrence of HAB. The cell concentration of Cochlonidium polykrikoides in the seawater was linearly proportional $\left(\mathrm{R}^{2}=\right.$ $0.9967)$ to the optical density at $300 \mathrm{~nm}$ for on-line real time measurement. Prevention of $\mathrm{HAB}$ could be achieved by the decrease of $\mathrm{pH}$ to below 5 with $\mathrm{CO}_{2}$ gas bubbling in the small area, a black curtain to block the sunlight during photosynthesis, and finally the Biogas $\left(\mathrm{H}_{2} \mathrm{~S}\right)$ from decomposed microorganisms could be bubbled into the water to prevent $\mathrm{HAB}$ in the early growth phase to remove the bioavailable iron $\mathrm{Fe}_{(\text {aq) }}^{2+}$ as insoluble iron sulfides $\left(\mathrm{FeS} / \mathrm{FeS}_{2}\right)$. It was recommended to spread the silica powder $(\sim 74 \% \mathrm{Si})$ over the water surface for sedimentation of algae for prevention of HAB in freshwater or in seawater. 


\section{Acknowledgements}

The author appreciates the assistances by the colleagues such as Prof. Soon-Ung Park (Center for Atmospheric and Environmental Modeling, Seoul National University) and Dr. Youngsin Chun (Asian Dust Research Lab, National Institute of Meteorological Research) in the work of Asian dust, Dr. Y. S. Seo and Dr. H. G. Kim (National Institute of Fisheries Sciences) in the data of Cochlonidium polykrikoides, Dr. Jay J. Lee (Geum River Environment Research Center, National Institute of Environmental Research), Dr. Dae Geun Kim (Department of Bioprocess Engineering, Chonbuk National University) and Prof. S. H. Jun (Department of Environmental Science Gangwon National University) for the data of chlorophyll $a$ in the freshwater and in batch culture of Chlorella Vulgaris, and dissolved phosphate in Korean Lakes, and Prof. J. G. Ryu (Korea National University of Transportation) for the suggestion in the wastewater treatment, respectively. This work was funded by The University of Suwon and G-LAND, Republic of Korea. Editing work undertaken by Professor Jonathan Wright is also greatly appreciated.

\section{Conflicts of Interest}

The author declares no conflicts of interest regarding the publication of this paper.

\section{References}

[1] Granēli, E. and Turner, J.T. (Eds.) (2006) Ecology of Harmful Algae. Ecological Studies, 1893, Springer. https://doi.org/10.1007/978-3-540-32210-8

[2] Resnick, B. (2018) Why Florida's Red Tide Is Killing Fish, Manatees, and Turtles, Vox.

[3] Edvardsen, B. and Imai, I. (2006) The Ecology of Harmful Flagellates within Prymnesiophyceae and Raphidophyceae in Ecology of Harmful Algae. In: Ecology of Harmful Algae, 67-79.

[4] Kim, T.J., Jeong, J.C., Seo, R.B., Kim, H.M., Kim, D.G., Chun, Y.S., Park, S.U., Yi, S.H., Park, J.J., Lee, J.H., Lee, J.J. and Lee, E.J. (2014) An Initiative Study on Relationship between Algal Blooms and Asian Dust for Regulation of Algal Blooms. KSBB Journal, 29, 285-296.

[5] Iwataki, M., Kawami, H., Matsuoka, K., Omura, T. and Fukuyo, Y. (2005) Phylogeny and Geographtical Distribution of Cochlonidium polykrikoides Population Collected from Annual Report 2005. PICES 14th Annual Meeting, Vladivostok, 29 September-9 October.

[6] Suh, Y.S., Jang, L.H., Lee, N.K. and Ishizaka, J. (2004) Feasibility of Red Tide Detaction around Korean Waters Using Satellite Remote Sensing. Fisheries Science and Technology, 7, 148-162. https://doi.org/10.5657/fas.2004.7.3.148

[7] Kim, T.J., Baskaran, M., Kim, D.G. and Hong, G.H. (2018) Searching of Optimal Location with the Least Undersea Sulfur Compounds for Efficient Iron Consumption by Phytoplankton. In review by American Journal of Climate Change, Scientific Research.

[8] Schrope, M. (2008) Oceanography: Red Tide Rising. Nature, 452, 24-26. https://doi.org/10.1038/452024a 
[9] Korea Gas Safety Company (2009) Test Report.

[10] PAQUES (2012) Operating \& Maintenance Manual.

[11] United States Geological Survey (2011) Volcano Hazards Program, 22.

[12] Duggen, S., Olagun, N., Croot, P., Hoffmann, L., Dietze, H., Delmelle, P. and Teschner, C. (2010) The Role of Airborne Volcanic Ash for the Surface Ocean Biogeochemical Iron-Cycle: A Review. Biogeosciences, 7, 827-844.

https://doi.org/10.5194/bg-7-827-2010

[13] Maher, B.A., Prospero, J.M., Mackie, D., Gaiero, D., Hesse, P.P. and Balkanski, Y. (2010) Global Connections between Aeolian Dust, Climate and Ocean Biogeochemistry at the Present Day and at the Last Glacial Maximum. Earth-Science Reviews, 99, 61-97. https://doi.org/10.1016/j.earscirev.2009.12.001

[14] Graham, L.E., Graham, J.M. and Wilcox, L.W. (2009) Algae. 2nd Edition, Pearson Education, Inc.

[15] Albert, S., O’Neil, J.M., Udy, J.W., Ahern, K.S., O'Sullivan, C.M. and Dennison, W.C. (2005) Lyngbya majuscula Blooms in Coastal Australian Waters: Upstream Causes and Downstream Effects. Marine Pollution Bulletin, 51, 428-437. https://doi.org/10.1016/j.marpolbul.2004.10.016

[16] Shin, H.Y. and Park, J.W. (2005) Micro Reduction of Iron Oxides and Removal of TCE Using the Iron Reduced by Iron Reducing Bacteria. Journal of Korean Society of Environmental Engineers, 27, 123-129.

[17] Shaked, Y. and Lis, H. (2012) Disassembling Iron Availability to Phytoplankton. Frontiers in Microbiology, 3, 123..

[18] Küpper, F.C. (2006) Marine Inorganic Biochemistry: From Photoreactive Siderophores to Iodide in Kelp.

[19] Martin, J.H. (1990) Glacial-Interglacial $\mathrm{CO}_{2}$ Change: The Iron Hypothesis. Paleoceanography, 5, 1-13.

[20] https://en.m.wikipedia.org/wiki/photosynthetically_active_radiation

[21] Yamaguchi, N., Ichijo, T., Sakotani, A., Baba, T. and Nasu, M. (2012) Global Dispersion of Bacterial Cells on Asian Dust. Scientific Reports, 2, Article No. 525. https://doi.org/10.1038/srep00525

[22] Tanaka, T.Y. and Chiba, M. (2006) A Numerical Study of Contributions of Dust Source Regions to the Global Dust Budget. Global and Planetary Change, 52, 88-104.

[23] Park, S.U. (2012) Transport and Deposition of Asian Dust Aerosols. International Bioaerosol Symposium, Seoul, 16 May 2012.

[24] Mills, M.M., Ridame, C., Davey, M., Roche, J.L. and Geider, R.J. (2004) Iron and Phosphorus Co-Limit Nitrogen Fixation in the Eastern Tropical North Atlantic. Nature, 429, 292-294.

[25] Ramos, A.G., Cuevas, E., Pérez, C., Baldasano, J.M., Coca, J., Redondo, A., so-Pérez, S., Bustos, J.J. and Nickovic, S. (2008) Saharan Dust and Bloom of Diazotrophic Cyanobacteria in the NW African Upwelling. Geophysical Research Abstracts, 10, EGU 2008-A-11763.

[26] Tan, S.C., Yao, X., Gao, H.W., Shi, G.Y. and Yue, X. (2013) Variability in the Correlation between Asian Dust Storms and Chlorophyll a Concentration from the North to Equatorial Pacific. PLoS ONE, 8, e57656.

[27] Chung, C.C., Chang, J., Gong, G.C., Hsu, S.C., Chiang, K.P. and Liao, C.W. (2011) Effects of Asian Dust Storms on Synechococcus Populations in the Subtropical 
Kurroshio Current. Marine Biotechnology (NY), 13, 751-763. https://doi.org/10.1007/s10126-010-9336-5

[28] Jeong, H.J., Park, J.Y., Nho, J.H., Park, M.O., Ha, J.H., Seong, K.A., Jeng, C., Seong, C.N., Lee, K.Y. and Yih, W.H. (2005) Feeding by Red-Tide Dinoflagellates on the Cyanobacterium Synechococcus. Aquatic Microbial Ecology, 41, 131-143.

[29] Zhang, X.Y., Gong, S.L., Shen, Z.X., Mei, F.M., Xi, X.X., Liu, L.C., Zhou, Z.Y., Wang, D., Wang, Y.Q. and Cheng, Y. (2003) Characterization of Soil Dust Aerosol in China and Its Transport and Distribution during 2001 ACE-Asia: 1. Network Observations. Journal of Geophysical Research, 108, 4261. https://doi.org/10.1029/2002JD002632

[30] Gao, Y., Smith, G.J. and Alberte, R.S. (2000) Temperature Dependence of Nitrate Reductase Activity in Marine Phytoplankton: Biochemical Analysis and Ecological Implications. Journal of Phycology, 36, 304-313. https://doi.org/10.1046/j.1529-8817.2000.99195.x

[31] Jeong, G.Y. and Chun, Y.S. (2006) Nanofiber Calcite in Asian Dust Its Atmospheric Roles. Geophysical Research Letters, 33, L24802. https://doi.org/10.1029/2006GL028280

[32] https://www.boundless.com/microbiology/microbial-ecology/nutrient-cycles/the-ir oncycle

[33] Paerl, H.W., Fulton, R.S., Moisander, P.H. and Dyble, J. (2001) Harmful Freshwater Algal Blooms, with an Emphasis on Cyanobacteria. The Scientific World Journal, 1, 76-113.

[34] Caccavo, F., Blakemore, R.P. and Lovley, D.R. (1996) A Hydrogen-Oxidizing, $\mathrm{Fe}(\mathrm{III})$-Reducing Microorganism from the Great Bay Estuary, New Hampshire. Applied and Environmental Microbiology, 58, 3211-3216.

[35] Wells, M.L., Price, N.M. and Bruland, K.W. (1995) Iron Chemistry in Seawater and Its Relationship to Phytoplankton: A Workshop Report. Marine Chemistry, 48, 157-182.

[36] Kudela, R.M., Seevave, S. and Cochlan, W.P. (2010) The Role of Nutrients in Regulation and Promotion of Harmful Algal Blooms in Upwelling Systems. Progress in Oceanography, 85, 122-135.

[37] Lewis, R., Parker, B., Gaffin, D. and Hoefnagels, M. (2009) Life. 6th Edition, McGraw-Hill, New York.

[38] Henley, W.J. and Yin, Y. (1998) Growth and Photosynthesis of Marine Synechococcus (Cyanophyceae) under Iron Stress. Journal of Phycology, 34, 94-103.

[39] Ahn, C.Y., Park, D.K., Kim, H.S., Chung, A.S. and Oh, H.M. (2004) K:Fe Ratio as an Indicator of Cyanobacterial Bloom in a Eutrophic Lake. Journal of Microbiology and Biotechnology, 14, 290-296.

[40] Karl, K. (1968) Turekian: Oceans. Prentice Hall, Upper Saddle River, NJ.

[41] Paerl, H.W. (1988) Nuisance Phytoplankton Blooms in Coastal, Estuarine, and Inland Waters. Limnology and Oceanography, 33, 823-843.

[42] Kawaguchi, T., Wahl, M.H., Aelion, C.M. and McKellar, H.N. (1994) Organically-Bound Ferrous Iron (Org.-Fe(II)) as an Indicator of Ecosystem Health: A Comparison of Suburbanized and Forested Streams in the Southeastern US. Journal of Environmental Science and Health, Part A, 29, 1761-1776.

[43] Ingle, R.M. and Martin, D.F. (1971) Prediction of the Florida Red Tide by Means of the Iron Index. Environmental Letters, 1, 69-74. 
[44] Alderkamp, A., Mills, M.M., van Dijken, G.L., Laan, P., Thuróczy, C., Gerringa, L.J.A., de Barr, H.J.W., Payne, C.D., Visser, R.J.W., Buma, A.G.W. and Arrigo, K.R. (2012) Iron from Melting Glaciers Fuels Phytoplankton Blooms in the Amundsen Sea (Southern Ocean): Phytoplankton Characteristics and Productivity. Deep Sea Research Part II: Topical Studies in Oceanography, 71-76, 32-48.

[45] Langroudi, H.E., Kamali, M. and Falahatkar, B. (2010) The Independent Effects of Ferrous and Phosphorus on Growth and Development of Tetraselmis suecica: An in Vitro Study. Caspian Journal of Environmental Sciences, 8, 109-114.

[46] Hosler, J.P. and Yocum, C.F. (1987) Regulation of Cyclic Photophosphorylation during Ferredoxin Mediated Electron Transport. Plant Physiology, 83, 965-969.

[47] Seeyave, S. (2009) Nitrogen Nutrition of Harmful Algae Blooms in Upwelling Systems. Ph.D. Thesis, University of Southampton, Southampton, UK.

[48] Schopf, J.W. and Walter, M.R. (1982) Origin and Early Evolution of Cyanobacteria: The Geological Evidence. In: Carr, N.G. and Whitton, B.A. Eds., The Biology of Cyanobacteria, Blackwell, Oxford, and University of California Press, Berkeley, 543-564.

[49] Saxton, M.A., Arnold, R.J., Bourbonniere, R.A., McKay, R.M.L. and Wilhelm, S.W. (2012) Plasticity of Total and Intracellular Phosphorus Quotas in Microcystis aeruginosa Cultures and Lake Erie Algal Assemblages. Frontiers in Microbiology, 3, 3.

[50] Schindler, D.W., Hecky, R.E., Findlay, D.L., Stainton, M.P., Parker, B.R., Paterson, M.J., Beaty, K.G., Lyng, M. and Kasian, S.E. (2008) Eutrophication of Lakes Cannot Be Controlled by Reducing Nitrogen Input: Results of a 37-Year Whole-Ecosystem Experiment. Proceedings of the National Academy of Sciences of the United States of America, 105, 11254-11258. https://doi.org/10.1073/pnas.0805108105

[51] Jun, S.H. and Park, Y.A. (1989) Forms and Mobility of Sediment Phosphorus in Lake Soyang. Korean Journal of Limnology, 22, 227-272.

[52] Min, Y.H. (2012) Method for Control of Algae Generation. Korean Patent 10-1160445.

[53] Moisander, P.H. and Paerl, H.W. (2000) Growth, Primary Productivity, and Nitrogen Fixation Potential of Nodularia spp. (Cyanophyceae) in Water from a Subtropical Estuary in the United States. Journal of Phycology, 36, 645-658. https://doi.org/10.1046/j.1529-8817.2000.99227.x

[54] https://en.wikipedia.org/wiki/Sulfite_oxidase

[55] Falkowski, P.G. and Raven, J.A. (1997) Aquatic Photosynthesis. Blackwell Science, Malden, MA.

[56] Lippemeier, S., Hartig, P. and Colijn, F. (1999) Direct Impact of Silicate on the Photosynthetic Performance of the Diatom Thalassiosira weissflogii Assessed by On- and Off-Line PAM Fluorescence Measurements. Journal of Plankton Research, 21, 269-283. https://doi.org/10.1093/plankt/21.2.269

[57] Healey, P., Coombs, J. and Volcani, B.E. (1967) Changes in Pigment Content of the Diatom Navicula pelliculosa (Bréb) Hilse in Silicon-Starvation Synchrony. Archiv für Mikrobiologie, 59, 131-142.

[58] Kong, Y. and Suh, Y.S. (2010) Climate Change and Marine Ecosystem. Academy Books, Korea.

[59] Harrison, P.J. (1976) Marine Diatoms Grown in Chemostats under Silicate or Ammonium Limitation. II. Transient Response of Skeletonema costatum to a Single Addition of the Limiting Nutrient. Marine Biology, 35, 187-199. 
[60] Leynaert, A., Nelson, D.M., Quéguiner, B. and Tréguer, P. (1993) The Silica Cycle in the Antarctic Ocean: Is the Weddell Sea Atypical? Marine Ecology Progress Series, 96, 1-15.

[61] Weir, R.G. (2004) Molybdenum Deficiency in Plants. Agfact AC. 4.

[62] WHO/SDE/WSH/03.04/11/Rev/1, Molybdenum in Drinking-Water.

[63] Emerson, S.R. and Huested, S. (1991) Ocean Anoxia and the Concentrations of Molybdenum and Vanadium in Seawater. Marine Chemistry, 34, 177-196.

[64] Ryan, A. and Cattle, S. (2010) Heavy Metal Contaminated Soils. 19th World Congress of Soil Science, Brisbane, Australia.

[65] Wilhelm, S.W. (1995) Ecology of Iron-Limited Cyanobacteria: A Review of Physiological Responses and Implications for Aquatic Systems. Aquatic Microbial Ecology, 9, 295-303. https://doi.org/10.3354/ame009295

[66] Paerl, H.W. and Fulton III, R.S. (2006) Chap. 8 Ecology of Harmful Cyanobacteria. In: Granéli, E. and Turner, J.T., Eds., Ecology of Harmful Algae, Springer, Berlin, 95-109.

[67] Watanabe, M.F. (1994) Culture of Toxic Blue-Green Algae. In: Watanabe, M.F., et al., Eds., Water Bloom of Blue-Green Algae and Their Toxins, University of Tokyo Press, Tokyo, 55.

[68] Nayak, S. and Prasanna, R. (2007) Soil pH and Its Role in Cyanobacterial Abundance and Diversity in Rice Field Soils. Applied Ecology and Environmental Research, 5, 103-113.

[69] National Institute of Fisheries Sciences (1997) Red Tides in Korean Coast.

[70] Moisander, P.H., Hench, J.L., Kononen, K. and Paerl, H.W. (2002) Small-Scale Shear Effects on Heterocystous Cyanobacteria. Limnology and Oceanography, 47, 108-119. 